\title{
Análise de fácies e ambientes deposicionais do Grupo Vazante na região da mina de Morro Agudo, Paracatu, noroeste do estado de Minas Gerais Facies analysis and depositional environments of the Vazante Group in the region of Morro Agudo mine, Paracatu, northwest of Minas Gerais state, Brazil
}

\author{
Marcus Paulo Sotero',2 (1), Fabrício de Andrade Caxito ${ }^{1}$ (D), Paulo Henrique Amorim Dias ${ }^{2}$ (D), Benjamim Augusto Sotero ${ }^{3}$ (D) \\ ${ }^{1}$ Universidade Federal de Minas Gerais - UFMG, Instituto de Geociências, Programa de Pós-Graduação em Geologia e Centro \\ de Pesquisas Manoel Teixeira da Costa - IGC-CPMTC, Campus Pampulha, Avenida Antônio Carlos, 6.627, CEP 31270-901, \\ Belo Horizonte, MG, BR (marcus.sotero@cprm.gov.br; caxito@ufmg.br) \\ ${ }^{2}$ Serviço Geológico do Brasil - CPRM, Belo Horizonte, MG, BR (paulo.dias@cprm.gov.br) \\ ${ }^{3}$ Petróleo Brasileiro S.A. - Petrobras, Macaé, RJ, BR (benjamimsotero@petrobras.com.br)
}

Recebido em 28 de março de 2018; aceito em 2 de abril de 2019

\begin{abstract}
Resumo
Rochas do Grupo Vazante afloram no noroeste do estado de Minas Gerais, em uma faixa contínua de aproximadamente $250 \mathrm{~km}$, da região de Vazante, ao sul, até Unaí, ao norte. Nessa região está localizada a mina de zinco e chumbo de Morro Agudo, que juntamente com os depósitos de Vazante, Ambrósia e Fagundes, todos hospedados no Grupo Vazante, compõe a principal província zincífera do país. Foram descritas, em seis testemunhos de sondagem e afloramentos de campo na região, 12 fácies sedimentares e quatro associações de fácies (AFs), que indicam deposição em ambiente de margem passiva mista carbonática-siliciclástica. A associação mais basal (AF01) é composta por pelitos e ritmitos silto-arenosos carbonosos, representando sedimentação em plataforma profunda de baixa declividade, em regime de transgressão marinha. Após a inundação máxima, em trato de mar alto, depositou-se a AF02 em ambiente de recife com barreiras em borda de plataforma, composta por dolomitos laminados com estromatólitos, dolarenitos e brechas dolareníticas, e ainda pelitos carbonáticos carbonosos com fácies diamictito. $\mathrm{O}$ abaixamento do nível relativo do mar gerou uma regressão forçada e a deposição da AF03 em trato de sistema do estágio de queda. É composta, na base, por diamictito argilo-carbonoso com fragmentos de AF02, passando a pelito e ritmito silto-arenoso. A retomada da subida do nível relativo do mar proporcionou a deposição da AF04 e ainda de rochas da AF03 em posição mais distal. AAF04 é composta por dololutitos argilosos laminados e maciços, e dolarenitos intraclásticos depositados em plataforma carbonática. O padrão de empilhamento observado sugere que a deposição de todas as unidades ocorreu progressivamente, em processo de subida do nível relativo do mar (tratos transgressivos e mar alto), de queda e da retomada da subida (mar baixo).
\end{abstract}

Palavras-chave: Grupo Vazante; Fácies sedimentares; Plataforma mista.

\begin{abstract}
Vazante Group rocks outcrop in the northwest of Minas Gerais state, in a continuous belt of approximately $250 \mathrm{~km}$, from the region of Vazante city, in the south, to Unaí city, in the north. In this region is the zinc and lead mine of Morro Agudo, which together with the deposits of Vazante, Ambrósia and Fagundes, all housed in the Vazante Group, make up the main zinc province of the country. Twelve sedimentary facies and four facies associations $(A F S)$ were described in six drill holes and outcrops, that indicate deposition in a carbonate-siliciclastic mixed passive margin setting. The most basal association is $A F 01$, composed by carbonaceous mudstone and silt-sand rhythmic, representing sedimentation in a deep platform of low slope angle, in a regime of marine transgression. After the maximum flood surface, in the highstand systems tract, $A F 02$ was deposited in a reef setting with a barrier at the platform edge. It is composed of laminated dolomites with stromatolites, dolarenites and dolarenite breccia, and carbonate carbonaceous mudstones with interleaved diamictite facies. The fall in relative sea level led to a forced regression and the deposition of $A F 03$ in a forced regressive system's tract. It is composed, at the base, by carbonaceous diamictite with $A F 02$ fragments, passing to mudstone and silt-sand rhythmithes. The return of the rise of the relative sea level provided the deposition of $A F 04$ and $A F 03$ rocks in a more distal position. AF04 is composed by laminated and massive argillaceous dololutite, and intraclastic dolarenite, deposited in carbonate marine platform. The observed stacking pattern suggests that the deposition of all units occurred progressively, in process of rising relative sea level (transgressive and highstand systems tracts), of falling sea level (forced regressive systems tract), and return of rising relative sea level (lowstand normal regression).
\end{abstract}

Keywords: Vazante Group; Sedimentary facies; Mixed platform. 


\section{INTRODUÇÃO}

A região de Morro Agudo está situada ao sul da cidade de Paracatu, noroeste de Minas Gerais. Nessa região está localizada a mina de zinco e chumbo de Morro Agudo, que juntamente com os depósitos de Vazante, Ambrósia e Fagundes, todos hospedados no Grupo Vazante (Dardenne et al., 1998; Dardenne, 2000), compõe a principal província zincífera do país. Trata-se de mineralizações hidrotermais de zinco alojadas em rochas carbonáticas (Dardenne, 1972, 1978; Romagna e Costa, 1988; Monteiro, 1997, 2002).

Existem notáveis diferenças entre os tipos de mineralização das regiões de Vazante e de Paracatu. A mineralização de Vazante é silicatada, possui forte controle estrutural, é hospedada em brecha hidrotermal, relacionada ao preenchimento por fluidos da Falha de Vazante, e o principal mineral-minério é a willemita $\left(\mathrm{Zn}_{2} \mathrm{SiO}_{4}\right)$ (Rigobello et al., 1988; Dardenne et al., 1998; Pinho, 1989; Monteiro, 1997, 2002). Já o minério de Morro Agudo é sulfetado e composto principalmente de esfalerita $(\mathrm{ZnS})$ e galena $(\mathrm{PbS})$ formando corpos estratiformes, associadas a dolarenitos e brechas dolomíticas a dolareníticas, principalmente das formações Morro do Calcário e Serra da Lapa (Dardenne, 1972; Madalosso e Valle, 1978; Romagna e Costa, 1988; Dardenne e Schobbenhaus, 2001; Paniago, 2011). Nesse segundo tipo de mineralização, a estratigrafia local é fator determinante para a ocorrência dos depósitos.

No presente artigo, é descrito o empilhamento estratigráfico do Grupo Vazante na região de Morro Agudo, bem como as fácies sedimentares, associações de fácies e os processos sedimentares associados, baseados em dados de campo e de testemunhos de furos de sondagem obtidos na região. Com base nesses dados, são discutidos o ambiente deposicional e a correlação das fácies.

\section{CONTEXTO GEOLÓGICO}

\section{Geologia regional}

A região estudada encontra-se inserida na porção centro-sul da Faixa Brasília, que é classicamente definida como um orógeno colisional neoproterozoico localizado na borda oeste do Cráton do São Francisco (Figura 1A) (Almeida, 1967, 1968, 1977; Dardenne, 2000; Valeriano et al., 2004). Faz parte do Domínio Tectônico da Zona Externa da Faixa Brasília e do Cinturão de Dobras e Empurrões e é caracterizada por cinturão de dobras e cavalgamentos com vergência para leste (Fuck, 1994; Fuck et al., 2005). Nesse contexto, pertence à porção mais externa do orógeno, próximo ao limite oeste do cráton, e é composta de unidades metassedimentares dobradas e metamorfizadas em baixo grau, pertencentes aos grupos Vazante, Canastra e Paranoá (Figura 1B) (Dardenne, 2000).

A faixa de ocorrência do Grupo Vazante, denominada de Faixa Vazante (Dardenne et al., 1998; Dardenne, 2000), estende-se por cerca de $250 \mathrm{~km}$ na direção N-S, com largura variando de 25 a $30 \mathrm{~km}$, e pode ser dividida em dois domínios, norte e sul, separados pela inflexão do Rio Escuro. Essa inflexão também faz a separação entre os domínios de ocorrência de mineralizações de zinco silicatado (sul) e sulfetado (norte), e ainda das rochas hospedeiras.

As rochas que compõem o hoje chamado Grupo Vazante foram inicialmente relacionadas ao Grupo Bambuí por diversos autores (e.g., Dardenne, 1972; Madalosso e Valle, 1978; Brandalise et al., 1980). Dardenne et al. (1998) e Dardenne (2000) redefiniram a Formação Vazante, que passou ao patamar de Grupo, não mais correlacionado à sedimentação de antepaís do Grupo Bambuí, constituído de uma espessa sequência marinha de margem passiva, pelítico-carbonática, de aproximadamente $5 \mathrm{~km}$ de espessura, dividida em cinco formações, resumidas na Figura 2.

A coluna estratigráfica proposta por Dardenne (2000) (Figura 2) foi formalmente definida na região da cidade de Vazante, Minas Gerais. Nesse local existem vários trabalhos que balizam o entendimento da estratigrafia e das mineralizações associadas (e.g., Dardenne, 2000, 2001; Dardenne et al., 1998; Monteiro, 1997, 2002; Oliveira, 2013; Baia, 2013). Dardenne (2000) ainda admite duas unidades na base do grupo: formações Santo Antônio do Bonito (porção mais inferior) e Rocinha, porém trabalhos mais recentes indicam que houve inversão tectônica na região, posicionando essas unidades mais novas abaixo de outras mais antigas (e.g., Formação Serra do Garrote), e correlacionam essas duas formações ao Grupo Bambuí (Rodrigues et al., 2012; Pinho et al., 2017; Misi et al., 2007, 2014; Marques et al., 2015).

Para a região de Paracatu, o empilhamento estratigráfico não é bem estabelecido, representado em uma coluna informal definida pelos geólogos da Mineração Termerid (Oliveira, 1998), e a correlação com a região de Vazante ainda é alvo de grande discussão.

\section{Estratigrafia local da região de Morro Agudo}

Na Região de Morro Agudo (Figura 3) afloram, da base para o topo, e normalmente de leste para oeste, as formações Serra do Garrote, Morro do Calcário e Serra da Lapa, do Grupo Vazante. Além dessas, ainda ocorrem na área a Formação Serra do Landim e o Grupo Canastra, as quais não são objeto deste estudo. 
As unidades estão estruturadas em faixas alongadas com direções preferencialmente NNE-SSW, com mergulho para NW (Figura 3). Os contatos dão-se na sua maioria por falhas de empurrão de baixo ângulo ou inversas de ângulo médio a alto.

A Formação Serra do Garrote aflora na porção mais a leste da área. É composta de um pacote relativamente homogêneo de pelito preto, carbonoso, finamente laminado e com intercalação de lâminas e camadas de ritmito silto-arenoso, também carbonoso, e de esparsas lentes de arenito fino a médio. Em afloramento, essas rochas frequentemente apresentam coloração em tons arroxeados ou róseos a esbranquiçados. A estimativa da espessura dessa unidade é dificultada pela intensa deformação observada, e na região da Serra da Pindaíba, a norte da área estudada, o furo PSB-10 intercepta $936,5 \mathrm{~m}$ dessa unidade, sem cortar a unidade em sua totalidade.
Aflorando a oeste da Formação Serra do Garrote e sotoposta estratigraficamente, ocorre a Formação Morro do Calcário. O contato entre as duas unidades se dá por falha reversa de médio a alto ângulo. Essa unidade compõe uma faixa com grandes variações de espessura, afinando em direção sul até o seu desaparecimento em superfície. Sua maior espessura observada é superior a $870 \mathrm{~m}$ na região da mina de Morro Agudo (PSB-05). É composta por uma espessa sequência dolomítica (dolomito laminado, dolarenito intraclástico, dolorrudito e brecha intraclástica) com intercalações de camadas e estratos de pelito carbonático com fácies diamictito. Representa a principal unidade hospedeira de mineralizações de $\mathrm{Zn}$ e $\mathrm{Pb}$ na região.

A Formação Serra da Lapa aflora em forma de faixa com direção preferencial NE-SW, afinando em direção sul e abrindo para norte. A maior espessura dessa unidade, superior a $640 \mathrm{~m}$, foi observada no furo PSB-09, na região
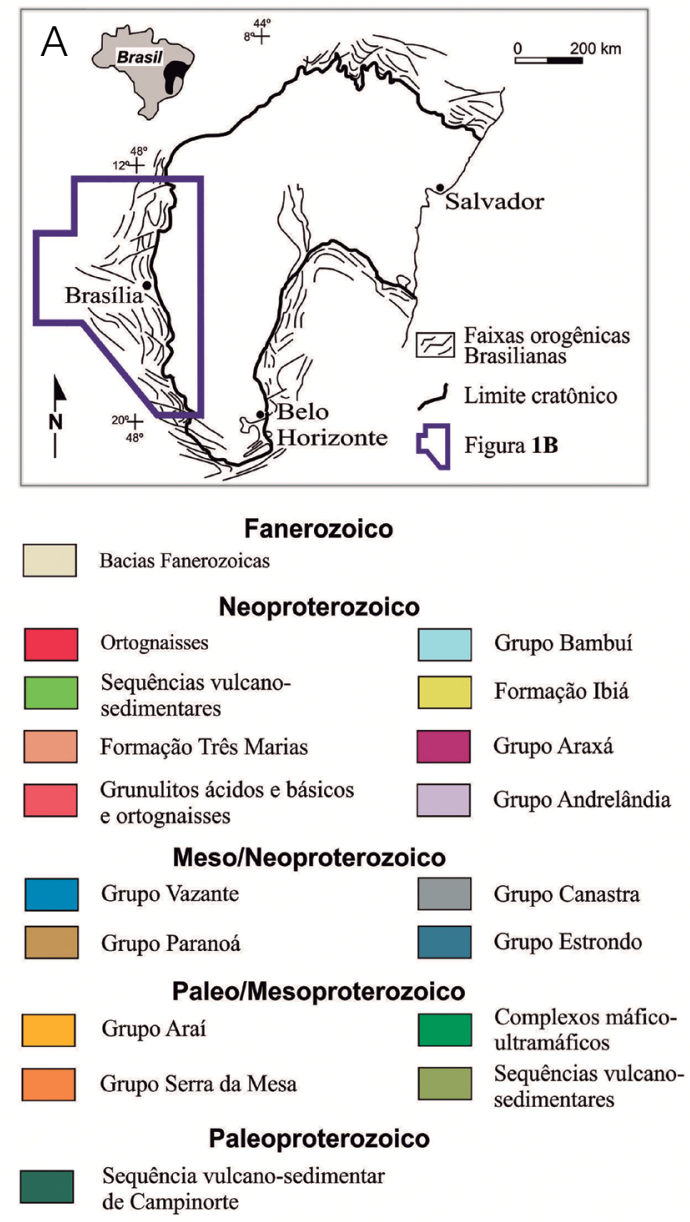

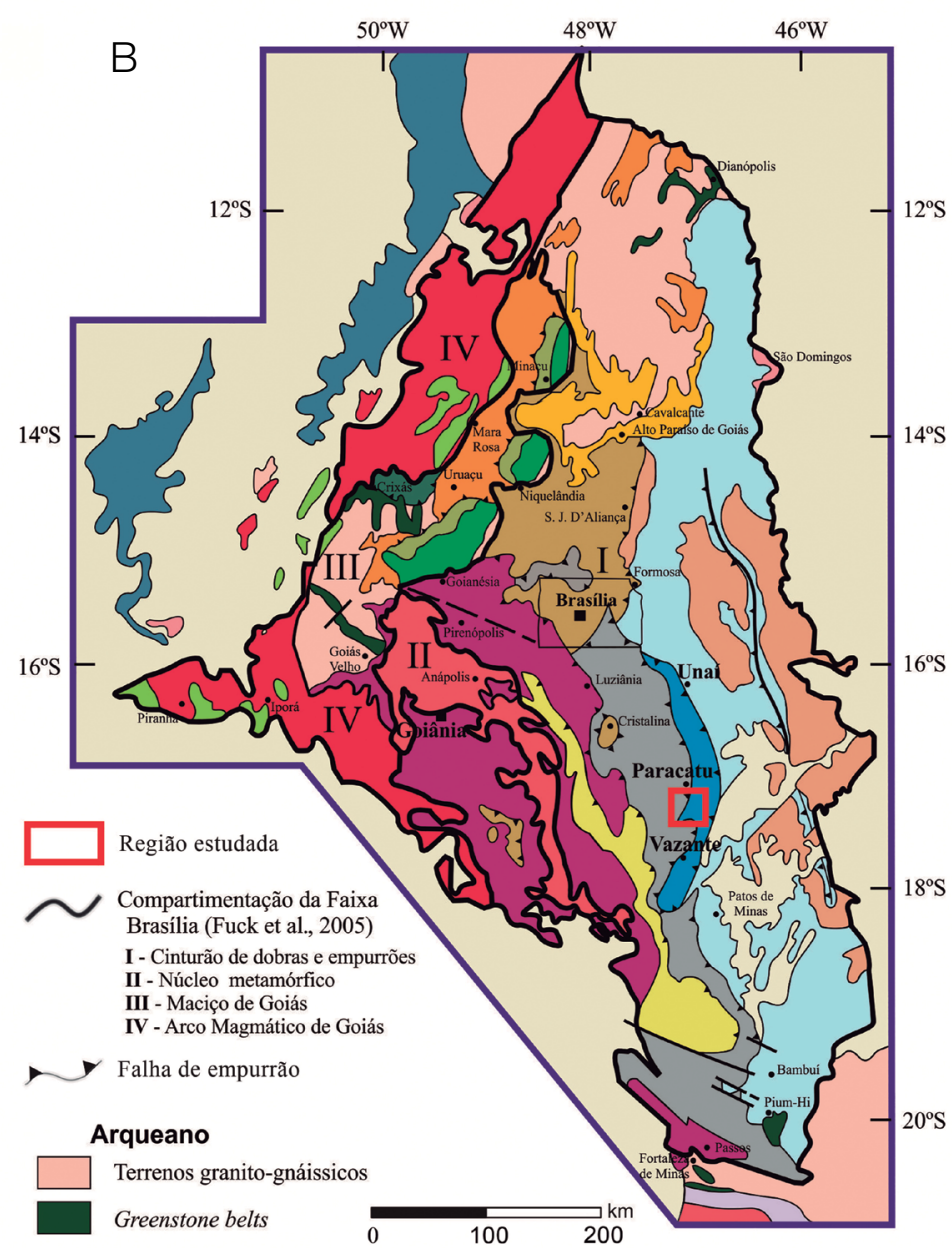

Greenstone belts

Figura 1. Mapa tectônico e localização da área. (A) Localização da Faixa Brasília no contexto do cráton São Francisco (limite cratônico compilado de Alkmim e Teixeira, 2017); (B) arcabouço geotectônico da Faixa Brasília (Dardenne, 2000) e compartimentação tectônica proposta por Fuck et al. (2005). 
da Serra do Landim. O contato com a Formação Morro do Calcário é erosivo, porém muitas vezes é visto apenas como tectônico por falha de empurrão, com falha normal posterior associada (e.g., região oeste da mina de Morro Agudo). Essa formação é composta de pacote contendo pelito carbonático carbonoso, diamictito, dolomito laminado, dolarenito, ritmito silto-argiloso e arenito. É comum a ocorrência de protomilonitos exibindo porfiroclastos rotacionados em ardósias carbonáticas, pelitos piritosos e dolomitos argilosos. Existem ocorrências minerais de esfalerita e galena associadas aos dolomitos e dolarenitos.

A Formação Serra do Landim aflora em faixa estreita, que também afina para sul e abre levemente para norte. É composta de pacote homogêneo de clorita-quartzo-sericita filito carbonático, esverdeado, com raras intercalações de metarenito impuro.
Tem a sua área tipo na serra de mesmo nome, onde chega a $408 \mathrm{~m}$ de espessura (PSB-09). O contato com a Formação Serra da Lapa dá-se por falhas de empurrão, chegando a formar $k l i$ ppen sinformes, como observado na região do furo PSB-08 (Figura 3). Essas duas unidades ainda chegam a ocorrer tectonicamente intercaladas (e.g., nos furos PSB-06 e PSB-11). A Formação Serra do Landim é historicamente conhecida por hospedar ocorrências minerais de malaquita.

A Formação Paracatu do Grupo Canastra é a unidade mais a oeste da área. O contato com a Formação Serra do Landim também ocorre por falhas de empurrão de baixo ângulo. Na região ocorrem duas subunidades: Membro Morro do Ouro (base), composto de filito carbonoso e raras lentes de quartzito; e Membro Serra da Anta (topo), composto de intercalação de quartzitos e filitos sericíticos a carbonosos. Na base dessa unidade, em uma

\begin{tabular}{|c|c|c|c|c|}
\hline Grupo & Formação & Membro & Descrição litológica & \\
\hline \multirow{11}{*}{$\underset{\substack{0 \\
\stackrel{D}{N} \\
\text { N }}}{>}$} & \multirow{2}{*}{$\begin{array}{l}\text { Serra da } \\
\text { Lapa }\end{array}$} & $\begin{array}{l}\text { Serra da } \\
\text { Lapa }\end{array}$ & $\begin{array}{l}\text { Ardósias carbonatadas cinzas e } \\
\text { lentes de dolomitos }\end{array}$ & 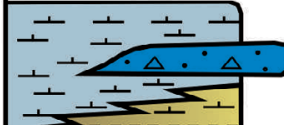 \\
\hline & & Serra do Velosinho & $\begin{array}{l}\text { Ardósias carbonatadas pretas, ritmitos } \\
\text { e diamictito }\end{array}$ & \\
\hline & $\begin{array}{l}\text { Morro do } \\
\text { Calcário }\end{array}$ & & $\begin{array}{l}\text { Bioherma estromatolítica, } \\
\text { fácies de brechas e dolarenitos, pelitos } \\
\text { carbonáticos carbonosos com fácies de } \\
\text { diamictito (mocambo) }\end{array}$ & 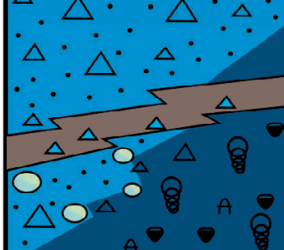 \\
\hline & \multirow{4}{*}{$\begin{array}{l}\text { Serra do } \\
\text { Poço Verde }\end{array}$} & $\begin{array}{l}\text { Pamplona } \\
\text { Intermediário }\end{array}$ & $\begin{array}{l}\text { Dolomitos rosados com esteiras } \\
\text { estromatolíticas, nódulos de barita } \\
\text { e gretas de ressecamento }\end{array}$ & 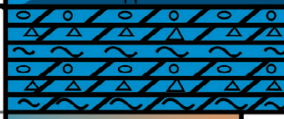 \\
\hline & & $\begin{array}{l}\text { Pamplona } \\
\text { Inferior }\end{array}$ & $\begin{array}{l}\text { Ardósias cinza a verde com intercalações } \\
\text { de dolomitos rosados }\end{array}$ & 方玄 \\
\hline & & $\begin{array}{l}\text { Morro do Pinheiro } \\
\text { Superior }\end{array}$ & $\begin{array}{l}\text { Dolomitos cinza-escuros com esteiras } \\
\text { estromatolíticas e birds eyes }\end{array}$ & $\begin{array}{l}\approx \approx \approx \approx \\
\approx \sim \approx \\
\approx \approx \sim\end{array}$ \\
\hline & & $\begin{array}{l}\text { Morro do Pinheiro } \\
\text { Superior }\end{array}$ & $\begin{array}{l}\text { Dolomitos cinza-claros a rosados com } \\
\text { intercalações de brechas e dolarenitos }\end{array}$ & 2013 \\
\hline & $\begin{array}{l}\text { Serra do } \\
\text { Garrote }\end{array}$ & & $\begin{array}{l}\text { Ardósias cinzas com lentes de quartzitos } \\
\text { esporádicas }\end{array}$ & 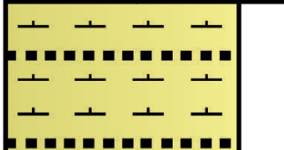 \\
\hline & \multirow{3}{*}{ Lagamar } & \multirow[b]{2}{*}{ Sumidouro } & Bioherma estromatolítica & 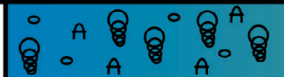 \\
\hline & & & $\begin{array}{l}\text { Calcários cinza-escuros e brechas } \\
\text { dolomíticas }\end{array}$ & \\
\hline & & Arrependido & Conglomerados & \\
\hline
\end{tabular}

Fonte: modificado de Dardenne (2000).

Figura 2. Coluna estratigráfica do Grupo Vazante. 
zona de boudins de quartzo, está hospedado o depósito de $\mathrm{Au}$ de Morro do Ouro a norte da área, em Paracatu.

\section{MATERIAIS E MÉTODOS}

Os testemunhos e os dados de sondagem utilizados neste trabalho foram obtidos pelo Projeto de Sondagem Bambuí (PSB), realizado nas décadas de 1970 e 1980 (Brandalise et al., 1980), quando foram realizados furos de sondagem estratigráfica com o objetivo de obter informações geológicas em subsuperfície sobre as ocorrências de zinco da região.

Foram reanalisados testemunhos de seis furos presentes na área (PSB-05, PSB-06, PSB-07, PSB-08, PSB-09 e PSB-11), totalizando 5.911,9 metros (Tabela 1).

A localização de cada furo pode ser visualizada na Figura 3. Foram coletadas 291 amostras de rocha nos testemunhos. Ainda, foram realizados levantamentos geológicos de 130 localidades de campo e coletadas 90 amostras dentro da área estudada.
Os litotipos observados foram descritos como rochas sedimentares, apesar da deformação sobreposta, que muitas vezes dificulta a observação das estruturas primárias.

A análise de fácies foi fundamentada pelas definições e sistemáticas de Reading (1996), Walker e James (1992) e Miall (1996). A individualização das fácies foi realizada por intermédio da descrição das litofácies, estruturas sedimentares e geometria. Foram agrupadas fácies geneticamente correlacionadas em associações de fácies (AFs) e, por fim, foram propostos um modelo deposicional e os paleoambientes. O código de cada fácies é composto de uma letra maiúscula, indicando o litotipo principal, e de duas minúsculas, indicando características particulares relevantes.

\section{RESULTADOS E DISCUSSÃO}

No presente trabalho sobre o Grupo Vazante, na região estudada, foram individualizadas e descritas fácies
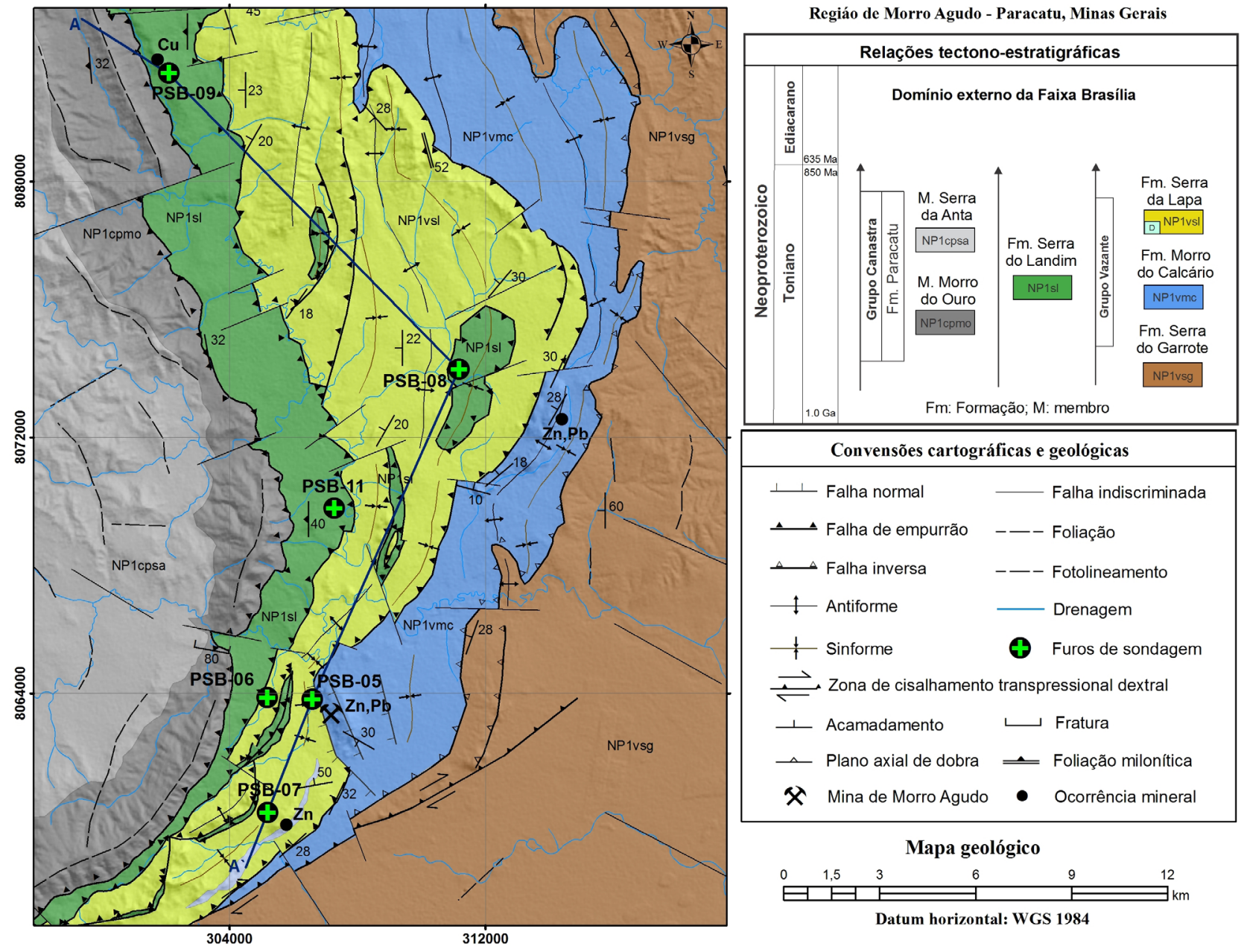

Fonte: modificado de Dias et al. (2018).

Figura 3. Mapa geológico da região de Morro Agudo, Paracatu, Minas Gerais. 
sedimentares agrupadas em AFs. As rochas metassedimentares do Grupo Canastra e da Formação Serra do Landim, que também afloram na região, não foram objeto deste trabalho.
A Tabela 2 sintetiza os resultados das descrições das fácies e de suas implicações em processos e ambientes sedimentares. As AFs estão organizadas em ordem de ocorrência na região, da base para o topo, AF01, AF02, AF03 e AF04.

Tabela 1. Localizações geográficas e profundidades dos furos de sondagem utilizados neste trabalho. As coordenadas UTM possuem Datum SAD-69, na zona 23S.

\begin{tabular}{lccccc}
\hline Furo & UTM-E & UTM-N & Profundidade $(\mathbf{m})$ & Toponímia & Município/UF \\
\hline PSB-05 & 306575,0 & 8063808,0 & $1.050,0$ & Mina de Morro Agudo & Paracatu/MG \\
PSB-06 & 305168,0 & 8063859,0 & 950,0 & Oeste da Mina de Morro Agudo & Paracatu/MG \\
PSB-07 & 305182,0 & 8060269,0 & 900,0 & Morro do Capão & Paracatu/MG \\
PSB-08 & 311164,0 & 8074116,0 & 953,2 & Bento Carmelo & Paracatu/MG \\
PSB-09 & 302096,0 & 8083371,0 & $1.056,2$ & Serra do Landim & Paracatu/MG \\
PSB-11 & 307259,0 & 8069772,0 & $1.002,5$ & Carrapato & Paracatu/MG \\
\hline
\end{tabular}

Tabela 2. Tabela-resumo da análise de fácies na região de Morro Agudo.

\begin{tabular}{|c|c|c|c|c|}
\hline AF & Fácies & Litologia & Estrutura/textura sedimentar & Processos e interpretação \\
\hline \multirow[b]{2}{*}{ AF04 } & Dic & $\begin{array}{l}\text { Dolomito maciço e } \\
\text { dolarenito intraclástico }\end{array}$ & Maciço, mal selecionado. & $\begin{array}{c}\text { Processos de tração e decantação } \\
\text { em plataforma carbonática }\end{array}$ \\
\hline & DIm & $\begin{array}{l}\text { Dololutito impuro } \\
\text { laminado/maciço }\end{array}$ & $\begin{array}{l}\text { Laminação plano-paralela; } \\
\text { porções maciças; recristalização. }\end{array}$ & $\begin{array}{c}\text { Deposição por processo de } \\
\text { decantação em plataforma } \\
\text { carbonática }\end{array}$ \\
\hline \multirow{3}{*}{ AF03 } & Rpa & $\begin{array}{l}\text { Ritmito pelito } \\
\text { carbonático e arenito }\end{array}$ & $\begin{array}{l}\text { Laminação plano-paralela, } \\
\text { às vezes onduladas } \\
\text { Estratificação cruzada tabular }\end{array}$ & $\begin{array}{c}\text { Alternância de processos de } \\
\text { decantação e tração; marinho com } \\
\text { correntes de turbidez }\end{array}$ \\
\hline & Dap & $\begin{array}{l}\text { Dolomito argiloso } \\
\text { e pelito carbonático }\end{array}$ & Laminação plano-paralela & $\begin{array}{c}\text { Deposição por decantação } \\
\text { em ambiente marinho } \\
\text { profundo a moderado }\end{array}$ \\
\hline & Dia & $\begin{array}{l}\text { Diamictito com matriz } \\
\text { argilo carbonosa e } \\
\text { fragmentos de dolomito }\end{array}$ & $\begin{array}{c}\text { Blocos muito mal selecionados } \\
\text { desordenados em matriz fina. } \\
\text { Fragmentos da AF02 }\end{array}$ & $\begin{array}{c}\text { Deposição por fluxo de detritos em } \\
\text { ambiente marinho } \\
\text { profundo a moderado }\end{array}$ \\
\hline \multirow{5}{*}{ AF02 } & Bim & Brecha intraclástica & $\begin{array}{l}\text { Maciça; fragmentos } \\
\text { moderadamente selecionados } \\
\text { angulosos a arredondados }\end{array}$ & $\begin{array}{c}\text { Fluxo de detritos e retrabalhamento } \\
\text { de fragmentos de dolarenitos, } \\
\text { dololutitos e dolomito laminado e } \\
\text { estromatolítico }\end{array}$ \\
\hline & Dim & Dolarenito intraclástico & $\begin{array}{l}\text { Rocha maciça, bem } \\
\text { selecionada, com pouca } \\
\text { ou nenhuma matriz; } \\
\text { intensa cimentação }\end{array}$ & $\begin{array}{l}\text { Retrabalhamento por processos } \\
\text { de tração de rochas carbonáticas } \\
\text { associadas ao recife }\end{array}$ \\
\hline & Pcc & $\begin{array}{c}\text { Pelito carbonático carbonoso } \\
\text { com matéria orgânica }\end{array}$ & Laminação plano paralela & $\begin{array}{l}\text { Deposição por decantação } \\
\text { em ambiente profundo, calmo }\end{array}$ \\
\hline & Dcd & $\begin{array}{c}\text { Diamictito com matriz } \\
\text { argilo carbonática e fragmentos } \\
\text { dolomíticos }\end{array}$ & $\begin{array}{l}\text { Matriz fina; fragmentos mal } \\
\text { selecionados; tendência de } \\
\text { diminuição dos fragmentos } \\
\text { em direção ao topo }\end{array}$ & $\begin{array}{c}\text { Fluxo de detritos e retrabalhamento } \\
\text { de fragmentos de dolarenitos, } \\
\text { dololutitos e dolomito laminado e } \\
\text { estromatolítico }\end{array}$ \\
\hline & Dle & $\begin{array}{l}\text { Dolomito laminado com } \\
\text { estromatólitos colunares }\end{array}$ & $\begin{array}{l}\text { Bio-laminações e colunas } \\
\text { estromatolíticas; } \\
\text { falhas sim-sedimentares }\end{array}$ & $\begin{array}{c}\text { Ambiente recifal com intensa } \\
\text { atividade biológica }\end{array}$ \\
\hline \multirow[b]{2}{*}{ AF01 } & Plc & $\begin{array}{c}\text { Pelito preto } \\
\text { laminado e carbonoso }\end{array}$ & Laminação plano paralela & $\begin{array}{l}\text { Deposição por decantação em } \\
\text { ambiente marinho profundo }\end{array}$ \\
\hline & Rsa & $\begin{array}{l}\text { Ritmito silto-arenoso } \\
\text { com matéria orgânica }\end{array}$ & $\begin{array}{l}\text { Laminação plano paralela, } \\
\text { às vezes ondulada }\end{array}$ & $\begin{array}{l}\text { Alternância de processos } \\
\text { de decantação e tração; } \\
\text { marinho profundo afetado } \\
\text { por correntes de turbidez }\end{array}$ \\
\hline
\end{tabular}

Plc: pelito laminado carbonoso; Rsa: ritmito silto-arenoso; Dle: dolomito laminado estromatolítico; Pcc: pelito carbonático carbonoso; Dcd: diamictito carbonoso com clastos de dolomito estromatolítico; Dim: dolarenito intraclástico maciço; Bim: brecha instraclástica maciça; Dia: diamictito; Dap: dolossiltito argiloso/pelito carbonático; Rpa: ritmito pelito-carbonático/arenito; DIm: dololutito impuro laminado/maciço; Dic: dolarenito intraclástico/dolarenito intraclastico conglomerático. 


\section{Fácies sedimentares}

\section{Pelito laminado carbonoso}

A fácies pelito laminado carbonoso (Plc) é constituída por pelitos pretos, finamente laminados, e piritosos (Figuras 4A e 4B). Ocorre abundância de matéria carbonosa, que dá a cor preta à rocha fresca. Em afloramento, quase nunca são observadas as características carbonosas por conta do elevado grau de intemperismo, conferindo coloração rósea, esbranquiçada e avermelhada (Figura 4A). em sericita e quartzo, também com abundância de matéria orgânica. Essa fácies compõe desde lâminas, camadas e estratos variando de espessuras centimétricas até de muitos metros.
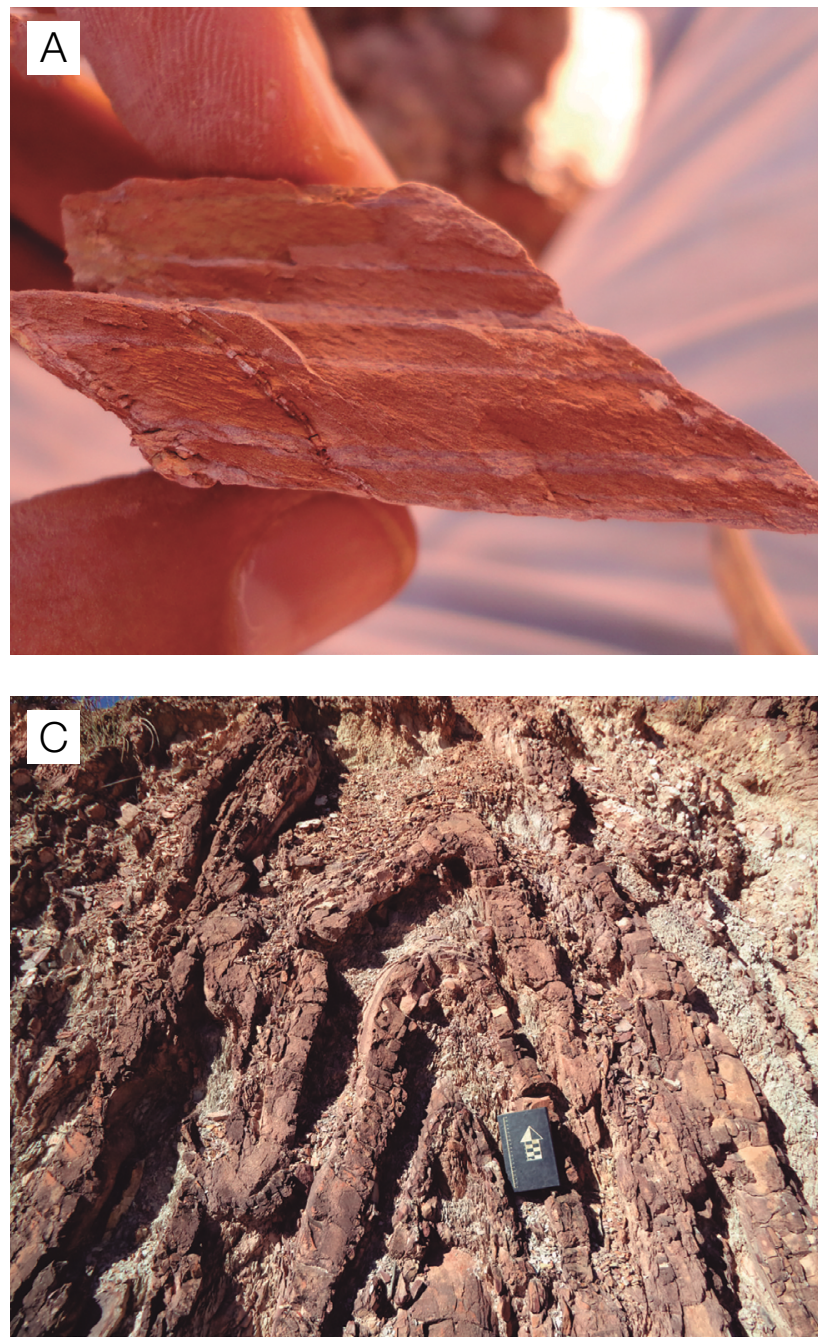
Ocorrem raras intercalações subordinadas de siltito rico

A estruturação sedimentar observada é de laminações plano-paralelas. As laminações estão muitas vezes tectonicamente dobradas e falhadas, o que dificulta a identificação das feições sedimentares.

Essa fácies representa deposição por decantação em ambiente aquoso de baixa energia, com profundidade moderada a alta, muito redutor e com abundância de matéria orgânica.

\section{Ritmito silto-arenoso}

A fácies ritmito silto-arenoso (Rsa) é constituída de intercalações rítmicas quartzo-sericítica de siltito e arenito muito fino, também com relevante contribuição carbonosa (Figuras 4C e 4D). Laminações plano-paralelas escuras e claras marcam o acamamento sedimentar, muitas vezes com
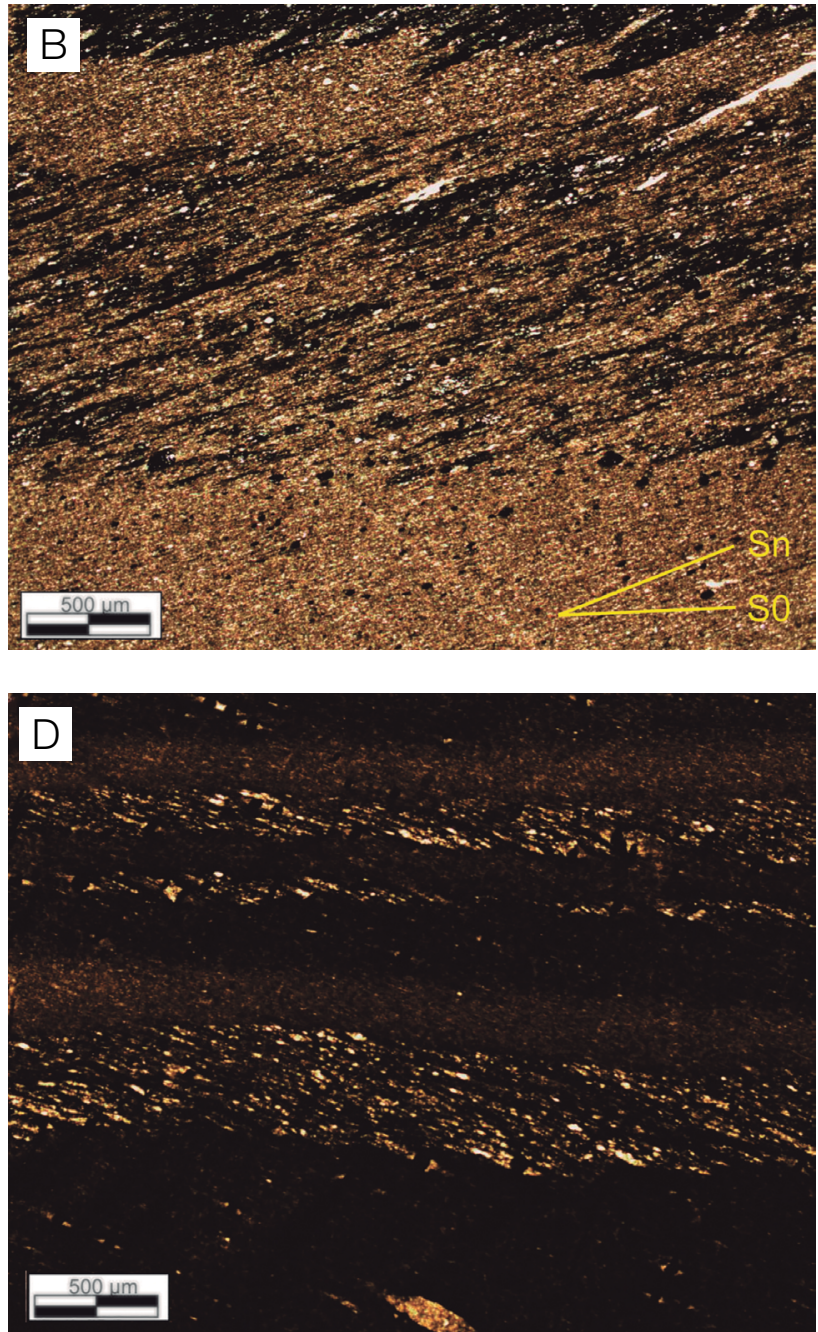

Figura 4. Fotos das fácies pelito laminado e ritmito silto-arenoso. (A) Pelito laminado com finas lâminas de siltito (amostra intemperizada); (B) fotomicrografia de pelito laminado com variação na proporção de matéria carbonosa; (C) afloramento de ritmito silto-arenoso dobrado pertencente à fácies ritmito silto-arenoso (afloramento ao norte da área estudada, porém na mesma unidade); (D) fotomicrografia de ritmito com lâminas pelíticas e outras com areia muito fina. 
ondulações primárias. Alternam-se lâminas milimétricas com material mais fino e escuro, compostas de argila e silte, e outras mais claras com maior concentração de silte e areia fina (Figura 4D).

Na região do Morro do Capão, essa fácies encontra-se intensamente deformada e venulada. A rocha é composta de grãos com tamanhos que variam de silte a areia fina de quartzo, plagioclásio e paletas de moscovita em matriz sericítica, muitas vezes com filmes de matéria carbonosa. Os grãos de quartzo são subangulosos a subarredondados. $\mathrm{O}$ acamamento é marcado pela variação da granulometria dos grãos e pela proporção grão/matriz.

Apesar do predomínio de ritmito, afloram ao norte da área, associadas a essa fácies, lentes de grauvaca mal selecionada, com grãos de quartzo e raro feldspato, variando de fino a grânulo, com matriz argilosa, a oeste do Morro de Bento Carmelo (Madalosso e Valle, 1978).

Essa fácies teria se originado por alternância entre processos de decantação e tração, o que indicaria alternância na energia do ambiente.

\section{Dolomito laminado estromatolítico}

A fácies dolomito laminado estromatolítico (Dle) é composta de dolomito laminado (dolossiltito/dololutito), com biolaminações irregulares, intercalado com estromatólitos colunares e estratos de dolomito maciço (Figura 5A). Em escala microscópica, as laminações estromatolíticas são compostas de micrita, às vezes mais claras, outras mais escuras. Dolomita esparítica ocorre cimentando a rocha de forma dispersa, muitas vezes preenchendo fraturas. Chega a ter espessura superior a $200 \mathrm{~m}$ em Morro Agudo.

A observação das características sedimentares da rocha é dificultada pela intensa recristalização e silicificação. É comum a presença de estilólitos sub-horizontais preenchidos por material escuro amorfo e fraturas preenchidas por dolomita esparítica.

Em campo, essa fácies é descontínua lateralmente. Interpreta-se que falhamentos de direção N-S e E-W se encontravam ativos durante a sedimentação, com rebaixamento e elevação de blocos, o que teria ocasionado truncamento lateral das fácies, rebaixando e elevando blocos da bacia. Isso faz com que ocorram truncamentos laterais de fácies diferentes.

Essa fácies comumente ocorre associada a níveis subordinados de dolarenito e brecha dolomítica e dolarenítica.

Representa a deposição por precipitação química e biológica, em ambiente calmo e com intensa atividade biológica, possivelmente compondo um recife. Essa fácies mostra que o ambiente passou por períodos de instabilidade do substrato, com presença de falhas normais sin-sedimentares e mudança na direção de crescimentos de colunas estromatolíticas.

\section{Pelito carbonático carbonoso}

A fácies pelito carbonático carbonoso (Pcc) é composta de rocha escura, muito fina, com acamamento sedimentar marcado pela proporção de matéria orgânica, alternando lâminas cinza pouco mais claro e mais escuro. A matriz da rocha é composta de sericita, dolomita microcristalina e matéria carbonosa. Ocorrem grãos tamanhos silte a areia muito fina de quartzo e fragmentos de carbonato. Muitos grãos de quartzo e quase todos os de carbonato estão estirados e alinhados com a foliação da rocha.

Representa deposição em ambiente de baixa energia, com predomínio de processo de decantação. A deposição dessa fácies ocorreu em ambiente profundo, calmo, com suprimento de carbonato intrabacinal.

\section{Diamictito carbonoso com clastos dolomitíticos}

A fácies diamictito carbonoso com clastos de dolomito estromatolítico (Dcd) é composta de diamictito com matriz argilo-carbonática e fragmentos de rochas dolomíticas, frequentemente com colunas de estromatólitos (Figura 5B). A matriz da rocha é composta de pelito cinza escuro e com relevante contribuição carbonosa. Os fragmentos variam desde frações grânulo até seixos. Todos os fragmentos identificados são de rochas dolomíticas, muitas vezes recristalizadas e silicificadas. Ocorrem alguns fragmentos mais preservados de dolomito e Dle. Aparenta haver tendência de diminuição dos tamanhos dos fragmentos em direção ao topo. Essa fácies, associada à Pcc, possui espessuras que variam de 55 a $140 \mathrm{~m}$.

Representa deposição por fluxo de detritos ou queda de blocos gerada por avalanches episódicas. O carbonato na matriz e os fragmentos de dolomito estromatolítico indicam proximidade com o recife, em ambiente calmo na maior parte do tempo, porém com frequente instabilidade.

\section{Dolarenito intraclástico maciço}

A fácies dolarenito intraclástico maciço (Dim) é constituída de dolarenito cinza suportado por grãos carbonáticos arredondados tamanho areia, raramente alongados, arranjados em empacotamento que varia de frouxo a apertado (Figura 5C). A maioria são intraclastos compostos de dolomita com cristalinidade muito fina, porém também são identificados dolarenito oolítico, oólitos, dolarenito e dolomito laminado (Figura 5D). Em alguns locais o tamanho dos intraclastos chegam até grânulo (Figura 5E). Alguns intraclastos possuem grãos de quartzo em meio à dolomita. Ocorrem fragmentos escuros de colofana. Ocorrem ainda estruturas arredondadas preenchidas por betume negro.

Na maioria das lâminas descritas ao microscópio, a rocha não possui matriz, com o espaço entre os grãos sendo 

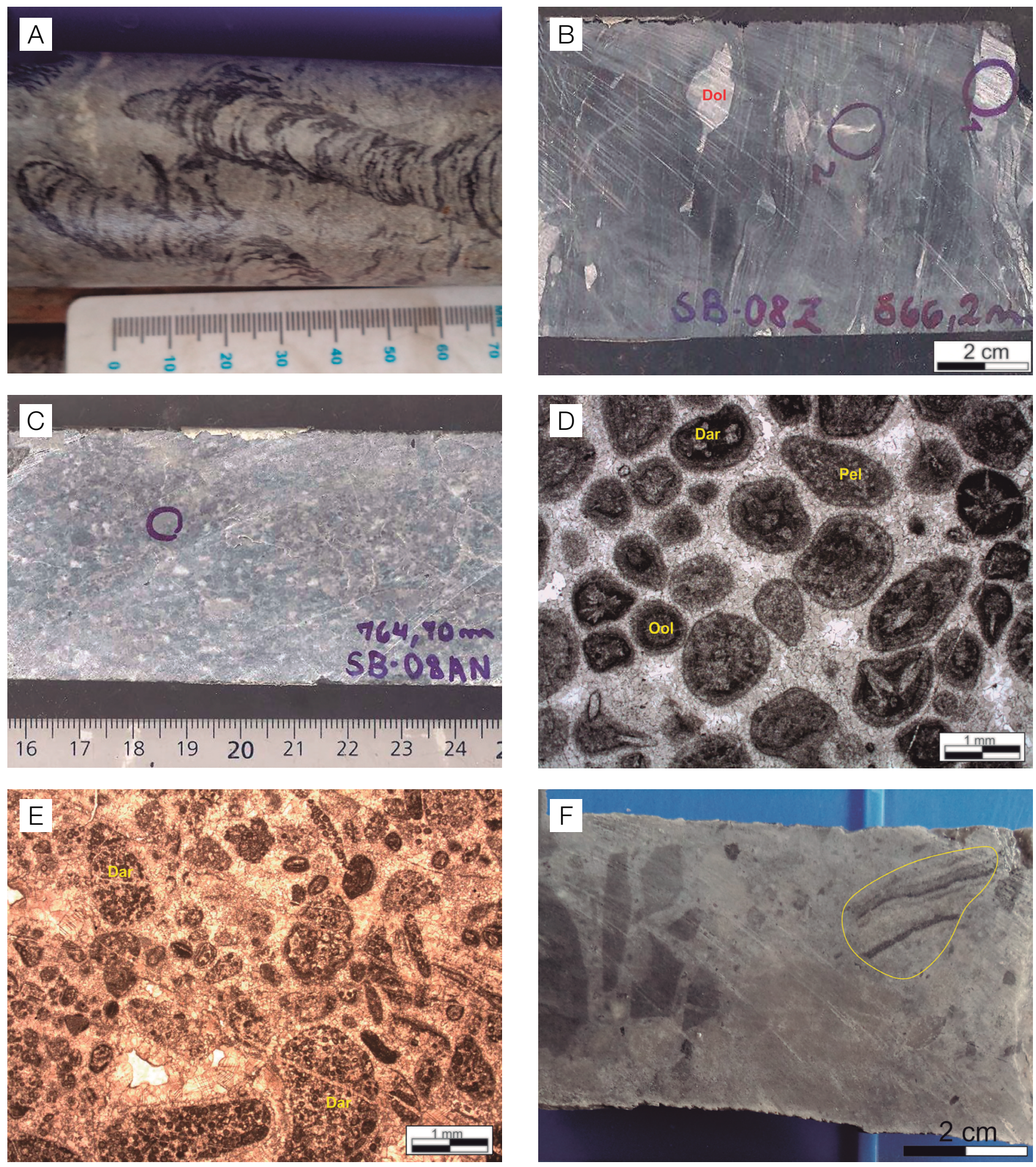

Dol: dolomito; Dar: dolarenito; Pel: peloides; Ool: ooides.

Figura 5. Fotos das fácies dolomito laminado estromatolítico, diamictito carbonoso com clastos de dolomito estromatolítico, pelito carbonático carbonoso, dolarenito intraclástico maciço e brecha instraclástica maciça. (A) Fácies dolomito laminado estromatolítico com construções estromatolíticas; (B) fácies diamictito carbonoso com clastos de dolomito estromatolítico com fragmentos de dolomito em matriz; (C) dolarenito cinza grosseiro (fácies dolarenito intraclástico maciço); (D) fotomicrografia de fácies dolarenito intraclástico maciço mostrando os intraclastos arredondados de ooides, peloides e fragmentos de dolarenito, envoltos em cimento dolomítico; (E) fotomicrografia de dolarenito microconglomerático com fragmentos arredondados de dolarenito e peloides; (F) brecha dolomítica com fragmentos angulosos de dolomito maciço e dolomito laminado (destaque em amarelo). 
preenchido por cimento de dolomita esparítica, esfalerita, pirita e rara galena. Os sulfetos ocorrem em aglomerados irregulares e preenchem os espaços entre os grãos, substituindo o cimento da rocha e também preenchendo porosidade intragranular e fraturas.

A rocha possui textura maciça, raramente com grãos alongados arranjados em uma direção preferencial, possivelmente marcando o acamamento sedimentar. É comum a presença de estilólitos sub-horizontais, muitas vezes preenchidos por material escuro carbonoso ou sulfetos.

Representa o retalhamento por processos de tração de fragmentos de rochas carbonáticas relacionadas ao recife.

\section{Brecha intraclástica maciça}

A fácies brecha instraclástica maciça (Bim) é composta de fragmentos de dolomito laminado, dolomito estromatolítico, dolomito maciço e dolarenito, imersos em matriz dolomítica. Os fragmentos são subarredondados a angulosos e possuem tamanhos que vão desde areia grossa a blocos. A matriz é maciça e o acamamento é raramente marcado por laminações. É comum a ocorrência de estilólitos sub-horizontais preenchidos por material escuro carbonoso. A sucessão composta por Bim e Dim possui espessura variando de 75 a $130 \mathrm{~m}$. Foram observados dois tipos de matriz: dolarenítica e dololutítica (Figura 5F).

Representa a deposição por fluxo gravitacional com transporte de seixos e blocos de rochas dolomíticas.

\section{Diamictito}

A fácies diamictito (Dia), correspondente à fácies de mesma denominação identificada por Santana (2011) na região de Fagundes, é composta de diamictito com matriz argilo carbonática carbonosa e fragmentos de dolomito, com variações na proporção matriz/arcabouço (Figura 6A). Os fragmentos variam desde frações grânulo até blocos. Na base da unidade ocorrem blocos com dimensões de alguns metros de espessura em sondagem, e a rocha possui característica de ortoconglomerado. Ocorre gradação entre ortoconglomerado e paraconglomerado. Todos os fragmentos identificados são de dolomito e dolarenito, muitas vezes recristalizados e silicificados, e ainda substituídos por sulfetos (Figura 6B). Nessa fácies não foram identificados fragmentos de dolomito estromatolítico, diferentemente da fácies Dle.

A matriz é escura, muito fina, composta de sericita, carbonato e matéria carbonosa. Ocorrem grãos tamanhos silte a areia muito fina de quartzo e carbonato. Em algumas porções, principalmente em direção ao topo, quase não são observados fragmentos (em testemunho), indicando a diminuição da sua proporção.

Não foram observados afloramentos dessa fácies na região estudada, tendo sido a mesma apenas identificada em testemunhos de sondagem, o que dificulta a descrição da forma de ocorrência, geometria e contatos.

Indica deposição por processos de fluxo de detritos que carregam lama (matriz) e blocos (clastos). O transporte se dá por fluxo denso de alta viscosidade por processo de decantação, com avalanches episódicas (queda de blocos). Azmy et al. (2008) sugerem que essa fácies pode representar registro de sedimentação glacio-marinha, porém neste trabalho não foram observadas evidências que caracterizem esse processo, assim como por Santana (2011).

\section{Dolossiltito argiloso/pelito carbonático}

A fácies dolossiltito argiloso/pelito carbonático (Dap) é composta de sequência argilo-dolomítica, formada por dolossiltito argiloso e pelito carbonático, ambos laminados e cinza escuros, e com contribuição de matéria carbonosa (Figura 6D). Os dois litotipos são muito semelhantes, distinguindo apenas pela proporção entre carbonato e argilominerais. Os grãos de quartzo e carbonato são tamanho silte, às vezes chegando a areia muito fina, e estão muito deformados, estirados com sombra de pressão e orientados segundo foliação milonítica persistente.

Essa fácies possui laminação plano-paralela, muitas vezes com variação da contribuição de sedimentos carbonosos.

A deposição dessa fácies ocorreu em ambiente de baixa energia, com predomínio de processo de decantação com mistura de sedimentos siliciclásticos e carbonáticos.

\section{Ritmito pelito-carbonático/arenito}

A fácies ritmito pelito-carbonático/arenito (Rpa) é composta de intercalações de ritmito pelito-carbonático, laminado e ondulado e com contribuição carbonosa, e arenito fino a médio cinza escuro com contribuição carbonosa. Os litotipos ocorrem em diferentes posições na estratigrafia e podem se repetir (Figura 6C). O contato normalmente é abrupto.

O ritmito possui laminações com variação da proporção de silte e areia fina. Os grãos são de quartzo e raro plagioclásio, variando de subangulosos a subarredondados. A porção fina da rocha é composta basicamente por sericita e micrita. Observa-se laminação plano-paralela, muitas vezes ondulada pela ação das ondas.

A porção arenosa possui baixa maturidade textural, com matriz argilo-carbonosa. Os grãos de quartzo variam de areia fina a média. Ocorrem alguns filmes argilosos descontínuos entre os estratos. Em algumas regiões, a rocha é maciça, mas no geral possui laminação, marcas onduladas e estratificação cruzada tabular (Figura 6E). Há o predomínio das porções mais argilosas, e ocorrem raros afloramentos em cristas onde ocorre maior proporção de arenito. 

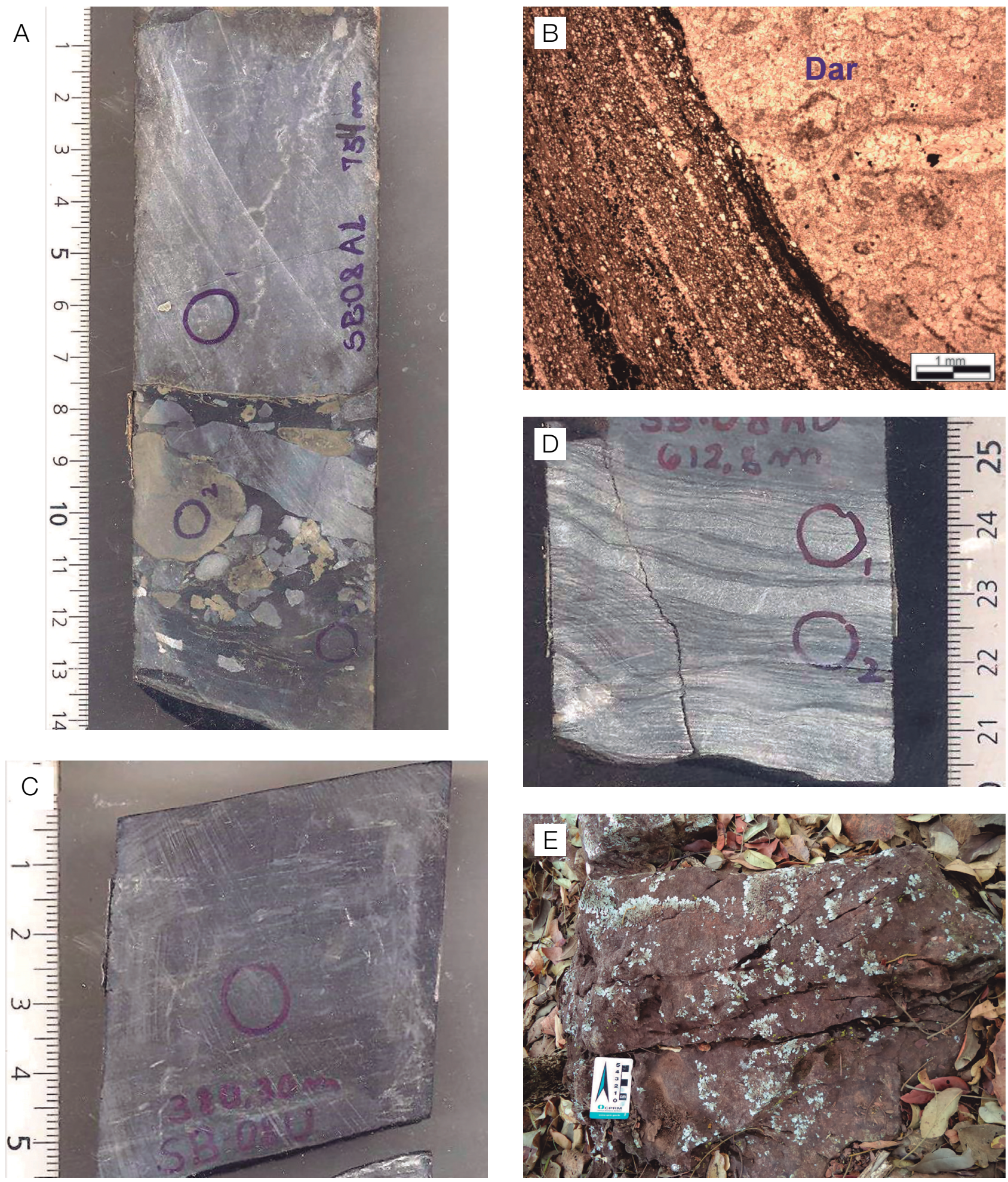

Dar: dolarenito intraclástico.

Figura 6. Fotos das fácies diamictito, ritmito pelito-carbonático/arenito e dolossiltito argiloso/pelito carbonático. (A) Fácies diamictito com fragmentos de dolomito cinza, alguns substituídos por sulfetos, em matriz argilo carbonática carbonosa; (B) fotomicrografia de fácies diamictito mostrando fragmento de dolarenito intraclastico e matriz argilo carbonática carbonosa; (C) fácies ritmito pelito-carbonático/arenito com laminações silto-argilosas cinza esverdeadas e arenosas mais claras; (D) fácies dolossiltito argiloso/pelito carbonático com rocha argilo carbonática carbonosa cinza escura; (E) estratos cruzados tabulares da fácies ritmito pelito-carbonático/arenito. 
Durante a sedimentação dessa fácies houve a alternância de processos de decantação e de tração em profundidades elevadas a moderadas.

\section{Dololutito impuro laminado/maciço}

A fácies dololutito impuro laminado/maciço (Dlm) é composta de dololutito e dolossiltito impuros, às vezes laminados e às vezes maciços, ambos argilosos e com matéria orgânica. Existe o predomínio do litotipo laminado. Esse tipo é marcado pela alternância de lâminas de até $1 \mathrm{~mm}$ de espessura, mais claras e outras mais escuras, com diferentes proporções de carbonato e argila (Figura 7A). Os grãos são de carbonato e quartzo e são finos, chegando ao tamanho silte, e a matriz é micrítica com material carbonoso.
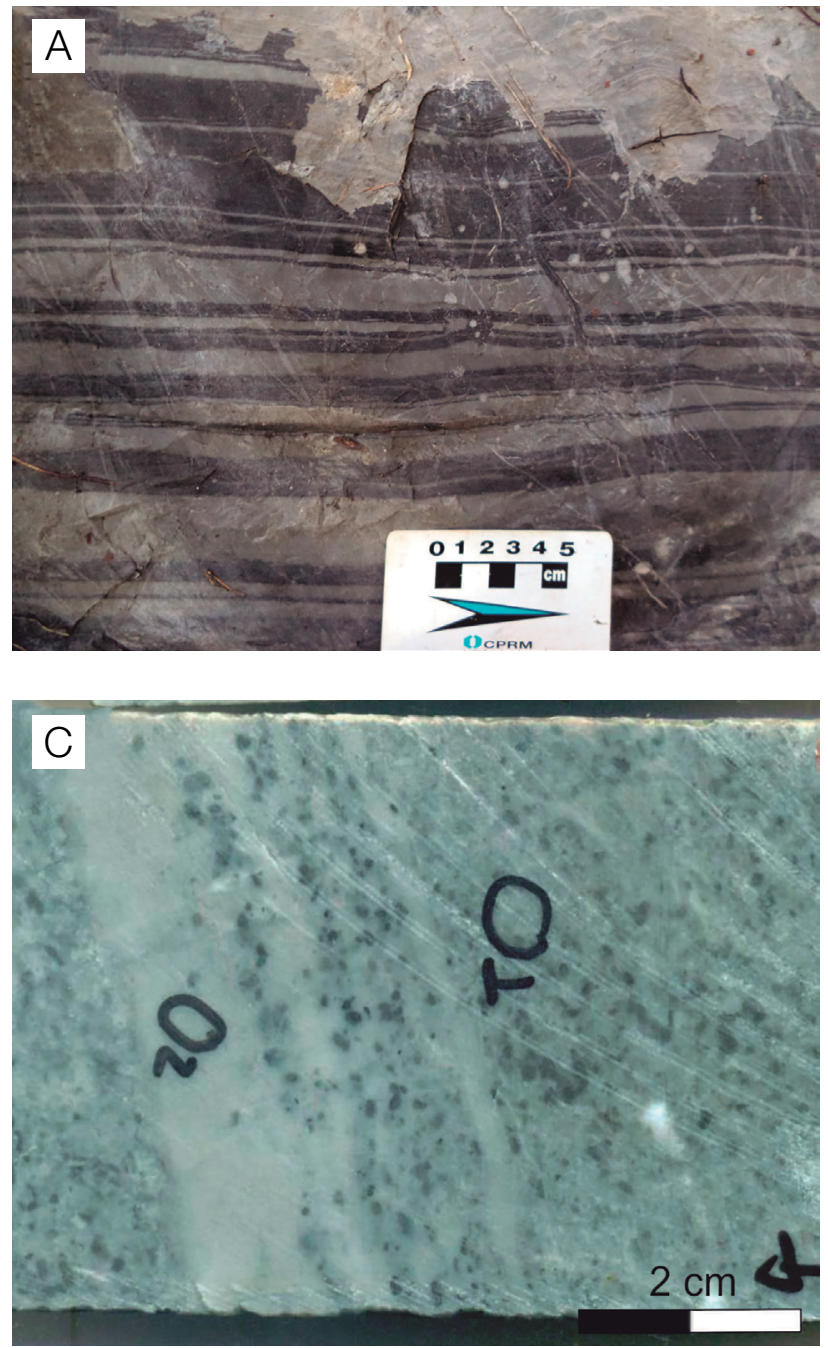

Já o dolomito maciço é composto por cristais de dolomita e grãos de quartzo e matriz argilosa carbonosa. Os grãos são subangulosos a angulosos, muitas vezes aparentando estar recristalizados, com tamanhos médios silte, chegando a areia muito fina. A matriz da rocha é composta de argila e micrita, e matéria orgânica formando filmes escuros associados a cristais euédricos muito finos de pirita.

Essa fácies mostra intensa recristalização da matriz carbonática, com predomínio de cristais de dolomita com cristalinidade variando desde fina a grossa (Figura 7B). Apesar disso, muitas vezes ainda guardam a estrutura original da rocha.

A Dlm encontra-se intensamente deformada, principalmente quanto maior a proporção de argila. Chegam a ocorrer
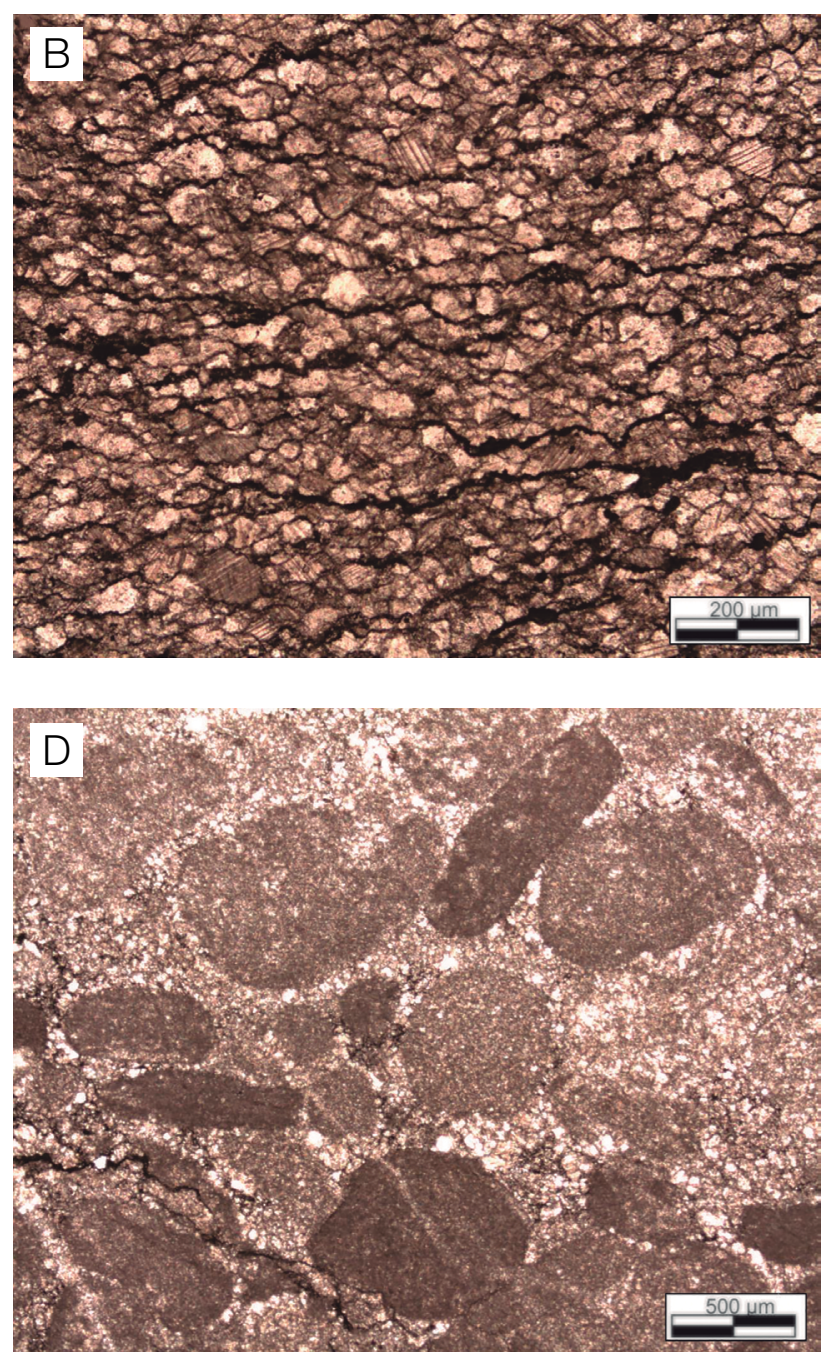

Figura 7. Fotos das fácies dololutito impuro laminado/maciço e dolarenito intraclástico/dolarenito intraclástico conglomerático. (A) Afloramento de dololutito impuro laminado/maciço laminado com porções cinza claro e escuro; (B) dolossiltito intensamente recristalizado com laminações irregulares de matéria carbonosa; (C) dolarenito grosso cinza claro pertencente à fácies dolarenito intraclástico/dolarenito intraclástico conglomerático; (D) fotomicrografia de dolarenito intraclástico grosso com fragmentos compostos de peloides. 
protomilonitos com porfiroclastos autólitos de porções maciças ou porfiroclastos de cristais de pirita.

A deposição dessa fácies deu-se predominantemente por processo de decantação em ambiente carbonático com energia, às vezes variando (laminado), às vezes contínua (maciço).

\section{Dolarenito intraclástico/dolarenito intraclástico conglomerático}

A fácies dolarenito intraclástico/dolarenito intraclástico conglomerático (Dic) é composta de dolarenito cinza intraclástico com matriz micrítica (Figura $7 \mathrm{C}$ ). Os grãos são predominantemente subarredondados a subangulosos com tamanho areia média, chegando a muito grossa e raramente grânulo, e quartzo subanguloso tamanho areia fina a média (Figura 7D). A rocha é suportada pelos grãos arranjados em empacotamento normal a apertado, muitas vezes levemente orientados, marcando o acamamento sedimentar. Os intraclastos são constituídos de dolomita com cristalinidade muito fina. $\mathrm{O}$ espaço intergranular é preenchido por matriz fina a média e cimento de dolomita esparítica com cristalinidade média. Possui espessura medida variando de $10 \mathrm{~m}$ no PSB-06 a 47 m no PSB-08.

Todas as amostras descritas encontram-se intensamente cimentadas e substituídas por grossos cristais de dolomita esparítica ou fibrosa, e mais raramente por sílica com diversas cristalinidades. Foi notada substituição total da rocha por sílica preservando a forma dos grãos. São observados filmes argilosos paralelos ao acamamento, comumente em porções com maior proporção de matriz.

$\mathrm{Na}$ deposição dessa fácies havia predomínio de processo de tração, porém com decantação associada. O grau de selecionamento dos grãos indica variação da energia do sistema e pouco retrabalhamento dos grãos.

\section{Associações de fácies}

As fácies descritas foram agrupadas em quatro AFs e relacionadas aos ambientes de sedimentação.

\section{Associação de fácies de plataforma marinha}

AAF de plataforma marinha (AF01) é constituída de sucessão relativamente homogênea de Plc e Rsa, que ocorrem em diversas posições dentro da unidade. $O$ contato entre as fácies é geralmente gradacional. Observa-se tendência do aumento de Plc e da contribuição carbonosa em direção ao topo.

Representa deposição em mar aberto, em águas com profundidades moderadas a elevadas, abaixo do nível de interferência de ondas, predominantemente calmas e com períodos episódicos de maior energia. Alternam-se os momentos de quietude, em que depositam as partículas mais finas por decantação, com momentos de maior energia, responsáveis pela deposição de silte e areia por tração. Essas porções mais grossas podem ser interpretadas como associadas a processos de correntes de turbidez em plataforma marinha de baixa declividade e em posição distal.

$\mathrm{O}$ ambiente era redutor e rico em matéria orgânica em quase toda a sequência, com a maior concentração de matéria carbonosa em direção ao topo. Possui padrão de empilhamento retrogradacional, com as fácies mais profundas no topo da unidade.

A espessura dessa unidade é desconhecida na região, e o furo PSB-07 interceptou $335 \mathrm{~m}$, sem atravessá-la totalmente. Essa AF foi a porção mais basal do Grupo Vazante identificada na região de Paracatu.

A AF01 pode ser correlacionada à Formação Serra do Garrote (Dardenne et al., 1998; Dardenne, 2000), classicamente descrita como ardósias cinza, ritmitos e lentes de arenitos posicionados na porção mais basal do Grupo Vazante.

\section{Associação de fácies de recife microbial}

$\mathrm{Na}$ AF de recife microbial (AF02) ocorre a coexistência de fácies resultantes de processos de alta e de baixa energia em ambiente predominantemente carbonático. A fácies Dle representa a bioherma estromatolítica in situ (fácies tipo recife ou reef), desenvolvida em ambiente com intensa atividade biológica e baixa energia. Já as fácies Dim, Bim e Dcd mostram o retrabalhamento de Dle, indicando representar os entornos do recife (fácies tipo forereef) que sofreu ação de ondas e retrabalhamento. $\mathrm{O}$ contato entre Dle e as fácies retrabalhadas é brusco.

A abundância de dolarenitos (Dim) e brechas (Bim) com matriz dolarenítica indica intenso retrabalhamento recifal por processos de tração, possivelmente por ondas. Já a presença da fácies Pcc evidencia que existiram condições de muito baixa energia, próximas ao recife, que possibilitaram a deposição de argila e micrita com matéria orgânica. Possivelmente se tratava de local mais fundo que o recife e protegido por barreiras (laguna ou back-reef). Essa porção foi frequentemente perturbada por avalanches episódicas causadas por falhas ativas.

A presença de brechas intraclásticas (Bim) e diamictitos (Dcd), e de falhas sin-sedimentares, evidenciam um substrato instável, com fluxos gravitacionais gerados por falhas e tremores, ativos durante a deposição dessa AF.

A seção mais espessa e completa da AF02 foi levantada no furo PSB-05, localizado sobre a atual mina de Morro Agudo, onde foram descritos $870 \mathrm{~m}$ da sequência. A AF02 pode ser correlacionada à Formação Morro do Calcário, proposta por Dardenne et al. (1998) e Dardenne (2000). É a principal sequência carbonática presente entre as cidades de Paracatu e Unaí.

O contato atual entre AF01 e AF02 foi identificado como tectônico, marcado por falha reversa de médio a alto ângulo, 
possivelmente reativada a partir de falha normal sin-sedimentar. Madalosso e Valle (1978) assumem esse contato como faciológico lateral, porém a deformação observada no contato dificulta a interpretação sobre a mudança do ambiente de deposição.

\section{Associação de fácies de margem de talude}

A base da AF de margem de talude (AF03) é marcada pela fácies Dia, gradando para Dap. A presença dessas duas fácies evidencia ambiente predominantemente calmo com deposição de argila e lama carbonática por decantação, porém com avalanches episódicas (queda de blocos). Ocorre tendência de gradação normal do tamanho dos fragmentos em direção ao topo. Podem estar relacionadas a avalanches submarinas ou pela mudança do lócus deposicional, sendo Dia representante da porção proximal e Dap, da distal.

Associado à Dap e Dia, posicionada mais para o topo da $\mathrm{AF}$, porém ainda intercalada, ocorre a fácies Rpa. Representa a presença de fluxos de correntes de tração associados.

A deposição da AF03 ocorreu em margem de talude, com profundidades moderadas a altas, abaixo do nível de interferência de ondas, instável, frequentemente afetada por tremores e fluxos de detritos. Havia relevante contribuição sedimentar da plataforma carbonática.

O contato entre AF03 e AF02 (e.g., nos furos PSB-07 e PSB-08) é marcado por descontinuidade brusca, irregular, reconhecido como um contato erosivo posteriormente tectonizado. Possui espessura máxima descrita no furo PSB09, superior a $645 \mathrm{~m}$.

Os fragmentos presentes em Dia são de dolomitos da AF02, o que indica que essa AF serviu de área fonte para AF03. Os fragmentos da AF02 são carregados por fluxo de detritos até posições distais da bacia.

A AF03 pode ser relacionada com a base da Formação Serra da Lapa na região de Paracatu, definida por Dardenne et al. (1998) e Dardenne (2000).

\section{Associação de fácies de plataforma carbonática}

A AF de plataforma carbonática (AF04) foi descrita tanto em sondagem como em afloramentos, principalmente na região de Morro Agudo, e em direção norte ela se torna mais escassa. Representa deposição em plataforma marinha mista, com maior influência de sedimentos carbonáticos. Possivelmente a deposição se deu em profundidades moderadas, com também moderado grau de retrabalhamento por processos de tração. Não foram observadas construções estromatolíticas dentro dessa associação de fácies. $\mathrm{O}$ contato entre Dlm e Dic é brusco.

Em relação à AF03, a AF04 ocorre posicionada acima, porém elas ainda podem ocorrer intercaladas, e representa fácies de ambiente mais raso do que a anterior. Interpreta-se que as duas fácies coexistiram lateralmente. O contato entre elas geralmente é brusco, contudo muitas vezes é observado como gradacional.

Em direção ao norte e ao oeste, ocorre o predomínio da AF03 em relação à AF04. Isso se dá provavelmente pelo aprofundamento da bacia em direção ao norte, passando a predominar fácies de margem de talude. Isso ainda indica que a região da inflexão do Rio Escuro (Figura 3) pode representar um paleoalto da bacia, interferindo no ambiente de sedimentação.

A AF04 pode ser relacionada à porção superior da Formação Serra da Lapa, definida por Dardenne et al. (1998) e Dardenne (2000), compondo o topo do Grupo Vazante.

\section{Inferências regionais}

As quatro AFs foram correlacionadas em quatro seções realizadas em testemunhos de sondagem. As sondagens estão localizadas no perfil A-A' (Figura 3) nas regiões, de sul para norte, do Morro do Capão (PSB-07), da Mina de Morro Agudo (PSB-05), de Bento Carmelo (PSB-08) e da Serra do Landim (PSB-09) (Figura 8A). Foram escolhidas as seções com menor influência tectônica e onde as relações estratigráficas aparentam estar normais.

A Figura 8B ilustra as inferências sobre as disposições e continuações laterais e em profundidade das AFs descritas na região.

A AF01 ocorre apenas no furo PSB-07 (Figura 8B), na base da sequência interceptada pelos furos. Por não ser interceptado pelos outros furos, o contato com a AF02 é inferido em profundidade para as outras regiões. Em campo, essa AF é estendida por grande faixa geográfica, tanto para nordeste como sudeste da área. É contínua e relativamente monótona, com alternância das fácies Plc e Rsa no decorrer da sua faixa de ocorrência, com a tendência do enriquecimento de Plc para o topo.

AAF02 foi atingida por cinco dos seis furos estudados. A espessura da AF afina em direção sul (Figuras 3 e 8B) e tem sua maior espessura observada na região da mina de Morro Agudo. O grande espessamento nessa região pode estar associado a falhas sin-sedimentares com direções ENE-WSW. Dentro dessa AF, as fácies Dim e Bim são contínuas nos topos de todas as seções. As fácies com relevante contribuição argilosa (Pcc e Dcd) não foram observadas na região sul, no Morro do Capão, mas tornam-se comuns em direção ao norte, com maior espessura observada no furo PSB-05 (Figura 8B). A fácies Dle é bem descrita na base da AF, principalmente nos furos PSB-05 e PSB-11, com espessa sequência de dolomito estromatolítico e laminado.

A AF03 mostra tendência de afinamento para S-SW (Figura 8B). A menor espessura observada foi vista em 
Morro do Capão, de $21 \mathrm{~m}$. Já em Morro Agudo não foi observada essa AF, com dois possíveis motivos: não deposição; ou a deformação observada nesse contato alterou o empilhamento original. Possui maior espessura vista no PSB-09 e há tendência do espessamento para norte. Além disso, em direção ao norte há o predomínio da fácies Rpa sobre as outras.

A AF04 predomina na região do centro ao sul da área, afinando em direção ao N-NW. As três seções que a interceptam (Figura 8B) possuem todas as fácies descritas, com o predomínio de Dlm, porém com camada bem marcada de Dic, que pode ser correlacionada entre os furos.

\section{Paleoambientes e evolução da bacia}

Todas as fácies e AFs descritas foram interpretadas como associadas a processos de sedimentação em ambiente de margem passiva marinha (e.g., Madalosso e Valle, 1978; Dardenne et al., 1998; Santana, 2011). Assume-se ainda que a bacia se desenvolveu às margens do Paleocontinente ou Cráton São Francisco (CSF) (Campos-Neto 1984a, 1984b; Almeida, 1977).

A proposta de evolução deposicional para a porção estudada do Grupo Vazante foi elaborada com base nos dados levantados em furos de sondagem e campo, em trabalhos

A

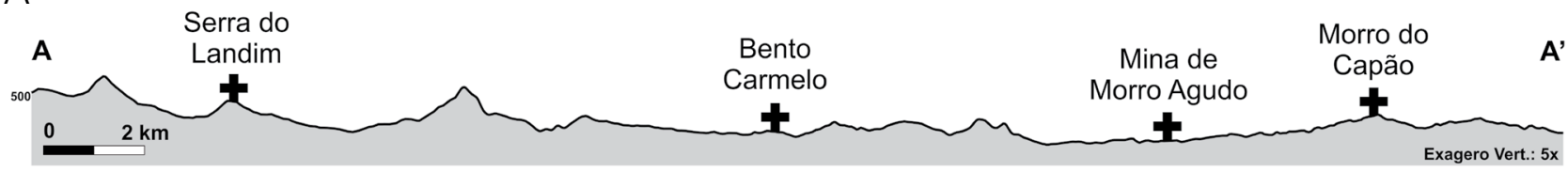

$\mathrm{B}$

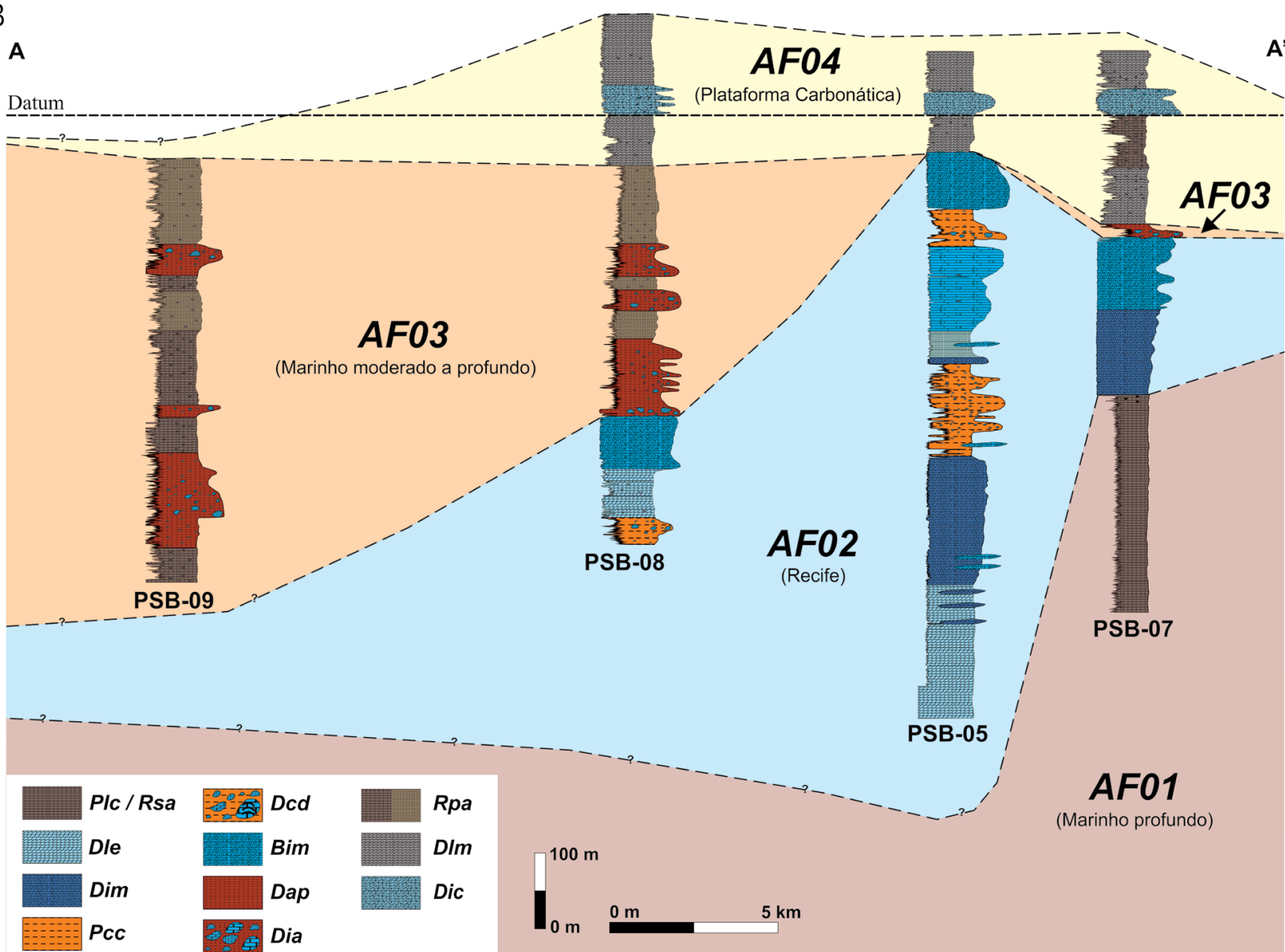

Plc: pelito laminado carbonoso; Rsa: ritmito silto-arenoso; Dle: dolomito laminado estromatolítico; Pcc: pelito carbonático carbonoso; Dcd: diamictito carbonoso com clastos de dolomito estromatolítico; Dim: dolarenito intraclástico maciço; Bim: brecha instraclástica maciça; Dia: diamictito; Dap: dolossiltito argiloso/pelito carbonático; Rpa: ritmito pelito-carbonático/arenito; Dlm: dololutito impuro laminado/maciço; Dic: dolarenito intraclástico/dolarenito intraclastico conglomerático.

Figura 8. Seção estratigráfica do Grupo Vazante na região estudada. (A) Localização de cada seção na topografia da região (seção composta $A-A$ ); (B) correlação entre as associações de fácies descritas nas seções estratigráficas. A base da fácies Dic foi usada como Datum. Perfis de sondagem compilados de Dias e Sotero, 2017a, 2017b, 2017c, 2017d. 
anteriores (e.g., Madalosso e Valle, 1978; Dardenne et al., 1998; Santanna, 2011; Oliveira, 2013) e em modelos e conceitos de análise de fácies e estratigrafia de sequências (e.g., Walker e James, 1992; Catuneanu, 2006; Catuneanu et al., 2009).

Vale salientar que o contato sedimentar basal do Grupo Vazante não foi observado, uma vez que, a oeste, a unidade é truncada por falhas de empurrão que o coloca em contato tectônico com o Grupo Bambuí, e em sondagem, não chegou a ser interceptado. Portanto, não se conhece a natureza dos estágios mais iniciais do Grupo Vazante na região de Paracatu. No entanto, na região de Lagamar é descrita uma sequência predominantemente carbonática na base da Formação Serra do Garrote, a Formação Lagamar (Dardenne e Campos Neto, 1976; Marques et al., 2015).

As Figuras 9A e 9B representam de forma esquemática a evolução da deposição da porção estudada do Grupo Vazante e o posicionamento das AFs descritas.

AAF01 foi a AF mais basal do Grupo Vazante identificada na região de Morro Agudo (Figura 9A). Representa a deposição em plataforma marinha siliciclástica de baixa declividade, em águas com profundidades moderadas a elevadas, com eventos episódicos de correntes de turbidez. Trata-se de uma plataforma de grandes dimensões, visto a distribuição geográfica dessa unidade, principalmente na direção N-S (cerca de $250 \mathrm{~km}$ ), desde as proximidades de Lagamar, ao sul, até Unaí, ao norte.

O padrão de empilhamento retrogradacional das fácies aponta para deposição em regime de transgressão marinha (Figura 9B). A porção proximal depositada durante a transgressão não foi observada, porém interpreta-se que seja correlata à Formação Lagamar. O topo da AF01, rico em argila e matéria orgânica, pode representar proximidade à superfície de inundação máxima. Essas porções ricas em matéria orgânica podem estar associadas a pontos potenciais para descolamentos tectônicos.

A continuação da subida do nível relativo do mar com geração de espaço de acomodação e maior aporte sedimentar possibilitou a deposição de carbonatos com padrão de empilhamento progradante, associados ao trato de mar alto (Figura 9B). A AF02 representa deposição em recife em borda de plataforma. $\mathrm{O}$ ambiente era relativamente raso, com influência de retrabalhamentos proximais. A subida do nível do mar com progradação da linha de costa possibilitou que os sedimentos siliciclásticos fossem depositados em posição mais continental, e os carbonáticos na plataforma. A deposição dessa AF está associada a falhas normais sinsedimentares (Figura 9A).

Uma regressão forçada expôs a AF02, gerando uma superfície erosiva de discordância subaérea (Figura 9B).

A AF03 pode ter sido depositada em trato de sistema do estágio de queda ou de regressão forçada, onde é muito comum a erosão das fácies mais elevadas e deposição em porção mais distal. $\mathrm{O}$ ambiente era de margem de talude, com profundidades moderadas a altas, abaixo do nível de interferência de ondas, instável, frequentemente afetada por fluxo denso de detritos que erodem na plataforma exposta e ao mesmo tempo em que se depositam diamictitos e turbiditos na quebra do talude. Essa AF teve como principal área fonte de fragmentos a AF02. $\mathrm{O}$ contato entre as duas unidades é marcado por uma superfície basal de regressão forçada (Figura 9B).

Com a retomada da subida do nível relativo do mar e o aumento da acomodação (trato de mar baixo), depositaram-se a AF04 e ainda a AF03, em posição mais distal (Figura 9B). A deposição da AF04 deu-se em plataforma carbonática, em profundidades moderadas, com pouco retrabalhamento por processos proximais.

O contato entre as AF03 e AF04 é de difícil delimitação, uma vez que as litologias podem ocorrer intercaladas (Figura 9A). Os empilhamentos e espessuras (Figura 8B) de AF03 e AF04 observados sugerem que, na região mais ao sul da área, a profundidade da bacia era menor do que em direção ao norte.

Os topos da AF03 (quando não sotopostos pela AF04) e da AF04 são truncados por falhas de empurrão com mergulho para oeste, que colocam a Formação Serra do Landim em contato tectônico. Isso dificulta a interpretação dos processos sedimentares dominantes na deposição do topo das unidades estudadas.

\section{CONCLUSÕES}

As fácies levantadas do Grupo Vazante na região de Paracatu são produtos de processos de sedimentação em ambiente de margem passiva marinha mista, de baixa declividade e com relevante atuação de falhas sin-sedimentares.

As AFs descritas variam lateralmente de espessura e composição. Além disso, há o predomínio de uma em relação à outra, dependendo da sua posição geográfica (e.g., AF03 e AF04), indicando que o paleorelevo da bacia atuou de maneira importante na deposição das fácies. Nesse sentido, a inflexão do Rio Escuro indica se tratar de um paleoalto geográfico que já existiria durante a deposição e influenciou na sedimentação do Grupo Vazante.

A porção estudada do Grupo Vazante representa um ciclo quase completo de subida e descida do nível relativo do mar. São descritos registros de tratos de sistema transgressivo (AF01), mar alto (AF02), regressão forçada (AF03) e mar baixo (AF03 e AF04). As presentes interpretações foram realizadas com observações de campo e testemunhos de sondagem, porém não se descarta a possibilidade de o empilhamento observado ter sido originado por tectonismo compressivo e que apenas estudos mais detalhados, com base em novas sondagens e estudos isotópicos (datações e perfilagem estratigráfica isotópica), poderiam comprovar a hipótese. 


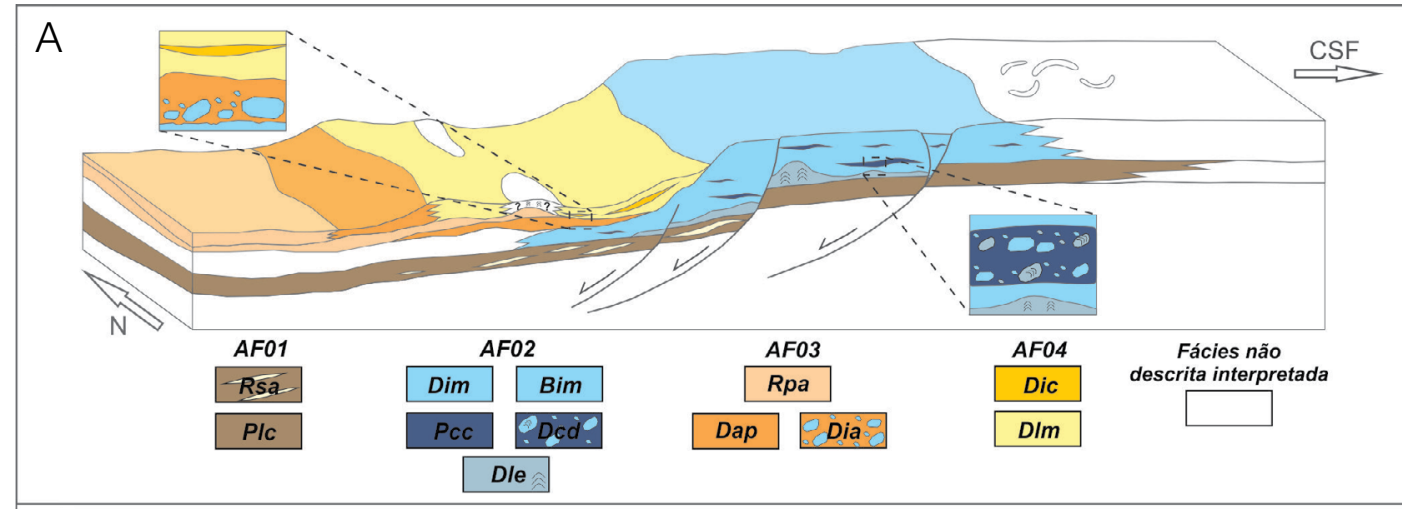

B
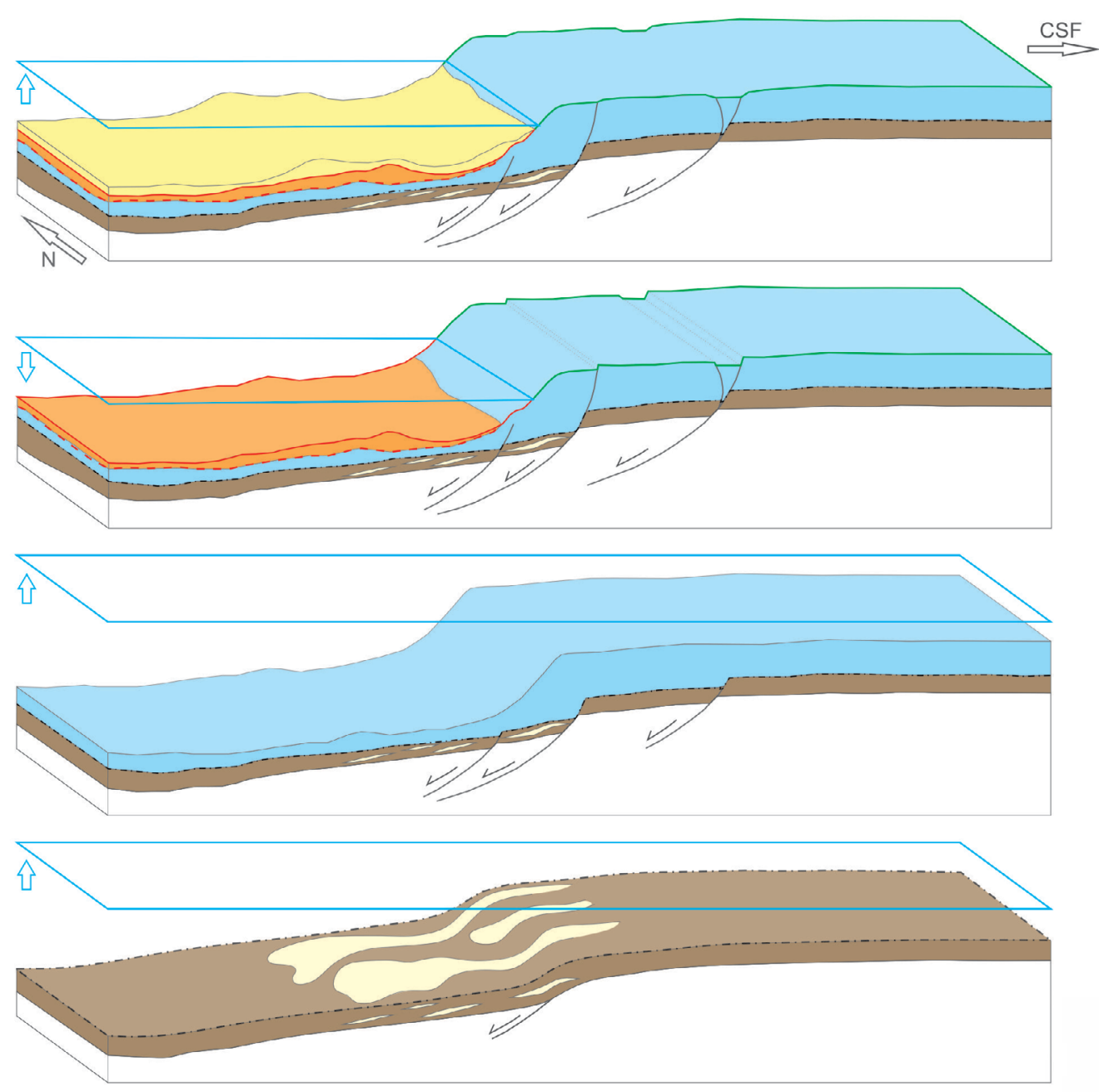

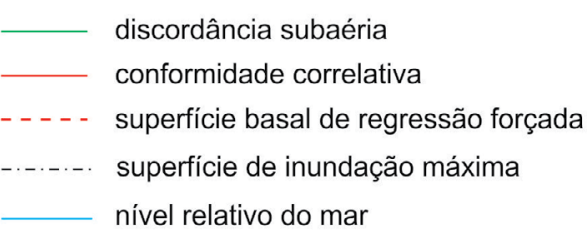

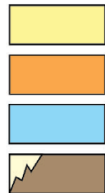

Regressão - mar baixo

Regressão forçada

Regressão - mar alto

Transgressão

Plc: pelito laminado carbonoso; Rsa: ritmito silto-arenoso; Dle: dolomito laminado estromatolítico; Pcc: pelito carbonático carbonoso; Dcd: diamictito carbonoso com clastos de dolomito estromatolítico; Dim: dolarenito intraclástico maciço; Bim: brecha instraclástica maciça; Dia: diamictito; Dap: dolossiltito argiloso/pelito carbonático; Rpa: ritmito pelito-carbonático/arenito; DIm: dololutito impuro laminado/maciço; Dic: dolarenito intraclástico/dolarenito intraclastico conglomerático.

Figura 9. Modelo esquemático de evolução da Bacia Vazante. (A) Representação simplificada das fácies sedimentares descritas e interpretadas do Grupo Vazante; (B) evolução dos estágios de deposição do Grupo Vazante. 


\section{AGRADECIMENTOS}

Ao Serviço Geológico do Brasil (CPRM), o apoio, a disponibilização dos testemunhos de sondagem e a autorização para publicação dos dados obtidos no decorrer dos projetos da empresa. A Marco Aurélio Pinheiro, a revisão e as relevantes sugestões ao manuscrito. Fabrício de Andrade Caxito é pesquisador do Conselho Nacional de Desenvolvimento Científico e Tecnológico (CNPq) e agradece o apoio recebido.

\section{REFERÊNCIAS}

Alkmim, F. F., Teixeira, W. (2017). The Paleoproterozoic Mineiro Belt and the Quadrilátero Ferrífero. In: M. Heibron, U. G. Cordani, F. F. Alkmim (Eds.), São Francisco Craton, Eastern Brazil, Regional Geology Reviews (71-74). Suíça: Springer. https://doi. org/10.1007/978-3-319-01715-0_5

Almeida, F. F. M. (1967). Origem e evolução da Plataforma Brasileira. Rio de Janeiro: DNPM/DGM, 36 p. (Boletim, 241).

Almeida, F. F. M. (1968). Evolução Tectônica do CentroOeste Brasileiro no Proterozóico Superior. Anais da Academia Brasileira de Ciências, 40 (Suplemento), 285-295.

Almeida, F. F. M. (1977). O Cráton do São Francisco. Revista Brasileira de Geociências, 7(4), 349-364.

Azmy, K., Kendall, B., Creaser, R. A., Heaman, L., Oliveira, T. F. (2008). Global correlation of the Vazante Group, São Francisco Basin, Brazil: Re-Os and $\mathrm{U}-\mathrm{Pb}$ radiometric age constraints. Precambrian Research, 164(3-4), 160-172. https://doi.org/10.1016/j. precamres.2008.05.001

Baia, F. H. (2013). Bechas Hidrotermais da Mina de Cercado e das Ocorrências de Olho d'água, Mata II e Pamplona: Implicações Metalogenéticas e Prospectivas para o zinco na região de Vazante, $M G$. Dissertação (Mestrado). Campinas: Instituto de Geociências Universidade de Campinas, $230 \mathrm{p}$.

Brandalise, L. A., Pimentel, G. B., Steiner, H. P., Soares, J., Mendes, J. R., Queiroz, N. F., Lima, O. M., Pádua, W. (1980). Projeto sondagens Bambui em Minas Gerais: relatório final. Belo Horizonte: DNPM/CPRM. v. 1.

Campos-Neto, M. C. (1984a). Geometria e fases de dobramento brasilianos superpostos no oeste de Minas Gerais. Revista Brasileira de Geociencias, 14(1), 60-68.
Campos-Neto, M. C. (1984b). Litoestratigrafia e evolução paleogeográfica dos Grupos Canastra e Paranoá (Região Vazante-Lagamar, MG). Revista Brasileira de Geociências, 14(2), 81-91.

Catuneanu, O. (2006). Principles of Sequence Stratigraphy. Amsterdã: Elsevier, 375 p.

Catuneanu, O., Abreu, V., Bhattacharya, J. P., Blum, M. D., Dalrymple, R. W., Eriksson, P. G., Fielding, C. R., Fisher, W. L., Galloway, W. E., Gibling, M. R., Giles, K. A., Holbrook, J. M., Jordan, R., Kendall, C. G. St. C., Macurda, B., Martinsen, O. J., Miall, A. D., Neal, J. E., Nummedal, D., Pomar, L., Posamentier, H. W., Pratt, B. R., Sarg, J. F., Shanley, K. W., Steel, R. J., Strasser, A., Tucker, M. E., Winker, C. (2009). Towards the standardization of sequence stratigraphy. Earth-Science Reviews, 92(1-2), 1-33. https:// doi.org/10.1016/j.earscirev.2008.10.003

Dardenne, M. A. (1972). A mineralização sulfetada de Pb-Zn de Morro Agudo (MG-Brasil). XXVI Congresso Brasileiro de Geologia. Resumos, Boletim 1, p. 55-56. Belém: SBG.

Dardenne, M. A. (1978). Geologia da região de Morro Agudo (MG). Boletim Núcleo Centro-Oeste, 7/8, 68-94.

Dardenne, M. A. (2000). The Brasilia fold belt. In: U. G. Cordani, E. G. Milani, A. Thomaz Filho, D. A. Campos (Eds.). Tectonic evolution of South America, p. 231-264. $31^{\text {st }}$ International Geological Congress. Rio de Janeiro.

Dardenne, M. A., Campos Neto, M. C. (1976). Geologia da região de Lagamar, Minas Gerais. XXIX Congresso Brasileiro de Geologia. Anais, p. 17. Ouro Preto: SBG.

Dardenne, M. A., Freitas-Silva, F. H., Souza J. C. F., Campos, J. E. G. (1998). Evolução tectono-sedimentar do Grupo Vazante no contexto da Faixa de Dobramentos Brasília. XL Congresso Brasileiro de Geologia. Resumos, p. 26. Belo Horizonte: SBG.

Dardenne, M. A., Schobbenhaus, C. (2001). Metalogênese do Brasil. Brasília: Editora da UnB, 392 p.

Dias, P. H. A., Sotero, M. P. (2017a). Perfil Composto PSB05. Escala 1:2.000. Projeto Paracatu-Unaí (ARIM-Áreas de Relevante Interesse Mineral): Belo Horizonte: Serviço Geológico do Brasil - CPRM.

Dias, P. H. A., Sotero, M. P. (2017b). Perfil Composto PSB07. Escala 1:2.000. Projeto Paracatu-Unaí (ARIM-Áreas de Relevante Interesse Mineral). Belo Horizonte: Serviço Geológico do Brasil - CPRM. 
Dias, P. H. A., Sotero, M. P. (2017c). Perfil Composto PSB08. Escala 1:2.000. Projeto Paracatu-Unaí (ARIM-Áreas de Relevante Interesse Mineral). Belo Horizonte: Serviço Geológico do Brasil - CPRM.

Dias, P. H. A., Sotero, M. P. (2017d). Perfil Composto PSB09. Escala 1:2.000. Projeto Paracatu-Unaí (ARIM-Áreas de Relevante Interesse Mineral). Belo Horizonte: Serviço Geológico do Brasil - CPRM.

Dias, P. H. A., Sotero, M. P., Matos, C. A., Marques, E. D., Marinho, M. S., Couto-Júnior, M. A. (2018). Área de Relevante Interesse Mineral - ARIM: Distrito Mineral de ParacatuUnai ( $\mathrm{Zn-Pb-Cu}$ ), MG. Belo Horizonte: CPRM-BH. 140 p. Série Províncias Minerais do Brasil. Programa de Geologia do Brasil - Série Províncias Minerais do Brasil, n. 14.

Fuck, R. A. (1994). A Faixa Brasília e a Compartimentação Tectônica da Província Tocantins. IV Simpósio de Geologia do Centro-Oeste. Anais, p. 184-187. Brasília: SBG.

Fuck, R. A., Pimentel, M. M., Soares, J. E. P., Dantas E. L. (2005). Compartimentação da Faixa Brasília. IX Simpósio de Geologia do Centro-Oeste. Atas, p. 26-27. Goiânia: SBG.

Madalosso, A., Valle, C. R. (1978). Considerações sobre a Estratigrafia e Sedimentologia do Grupo Bambuí na Região de Paracatu - Morro Agudo (MG). XXX Congresso Brasileiro de Geologia. Anais, 2, 622-634. Recife: SBG.

Marques, C. S. S., Uhlein, A., Oliveira, G. D., Uhlein, G. J., Sial, A. N., Alvarenga, C. J. S. (2015). Geologia e Quimioestratigrafia Isotópica do Grupo Vazante em Lagamar, MG. Geonomos, 23(1), 26-41. https://doi.org/10.18285/ geonomos.v23i1.659

Miall, A. D. (1996). The geology of fluvial deposits: sedimentary facies, basin analysis, and petroleum geology. Milão: Springer, 582 p.

Misi, A., Kaufman, A. J., Veizer, J., Powis, K., Azmy, K., Boggiani, P. C., Gaucher, C., Teixeira, J. B. G., Sanches, A. L., Iyer, S. S. (2007). Chemostratigraphic correlation of Neoproterozoic successions in South America. Chemical Geology, 237(2), 143-167. https://doi.org/10.1016/j. chemgeo.2006.06.019

Misi, A., Azmy, K., Kaufman, A. J., Oliveira, T. F., Sanches, A. L., Oliveira, G. D. (2014). Review of the geological and geochronological framework of the Vazante sequence, Minas Gerais, Brazil: implications to metallogenic and phosphogenic models. Ore Geology Reviews, 63, 76-90. https://doi.org/10.1016/j.oregeorev.2014.05.002
Monteiro, L. V. S. (1997). Contribuição à gênese das mineralizações de zinco da Mina de Vazante, MG. Dissertação (Mestrado). São Paulo: Instituto de Geociências - Universidade de São Paulo, 159 p. https://doi.org/10.11606/D.44.1997. tde-22082013-142638

Monteiro, L. V. S. (2002). Modelamento metalogenético dos depósitos de zinco de Vazante, Fagundes e Ambrósia, associados ao Grupo Vazante, Minas Gerais. Tese (Doutorado). São Paulo: Instituto de Geociências, - Universidade de São Paulo, 317 p. https://doi.org/10.11606/T.44.2002. tde-08062013-111126

Oliveira, T. F. (1998). As Minas de Vazante e de Morro Agudo. Workshop dos depósitos minerais brasileiros de metais base. Salvador: UFBA/ADIMB.

Oliveira, G. D. (2013). Reconstrução paleoambiental e quimioestratigrafia dos carbonatos hospedeiros do depósito de zinco silicatado de Vazante, MG. Dissertação (Mestrado). Brasília: Instituto de Geociências - Universidade de Brasília, 86 p.

Paniago, L. N. (2011). Caracteristicas descritivas e genéticas do depósito de Zn-Pb de Morro Agudo. Dissertação (Mestrado). Brasília: Instituto de Geociências - UnB.

Pinho, J. M. M., Dardenne, M. A., Rigobello, A. E. (1989). Evolução tectônica da mineralização de zinco de Vazante. $V$ Simpósio de Geologia do Núcleo Minas Gerais, Anais, v. 110, p. 275-276. Belo Horizonte: SBG.

Pinho, J. M. M., Féboli, W. L., Signorelli, N., Tuller, M. P., Brito, D. C., Ribeiro, J. H., Baptista, M. C., Silva, R. N. (2017). Geologia e recursos minerais das folhas: Cabeceira Grande, Unai, Ribeirão Arrojado, Serra da Aldeia, Serra da Tiririca, Paracatu, Guarda-Mor, Arrenegado, Coromandel, Lagamar, Monte Carmelo e Patos de Minas. Escala 1:100.000. 344 p. Belo Horizonte: CPRM.

Reading, H. G. (Ed.). (1996). Sedimentary Environments: Process, Facies and Stratigraphy. Oxford: Blackwell, 688 p.

Rigobello, A. E., Branquinho, J. A., Dantas, M. G. S., Oliveira, T. F., Neves-Filho, W. (1988). Mina de zinco de Vazante. In: C. Shobbenhaus, C. E. S. Coelho (Eds.). Principais depósitos minerais do Brasil (3, 101-110). Rio de Janeiro: DNPM.

Rodrigues, J. B., Pimentel, M. M., Buhn, B., Matteini, M., Dardenne, M. A., Alvarenga, C. J. S., Armstrong, R. A. (2012). Provenance of the Vazante Group: New U-Pb, Sm-Nd, Lu-Hf isotopic data and implications for the tectonic evolution of the Neoproterozoic Brasília Belt. Gondwana Research, 21(2-3), 439-450. https://doi.org/10.1016/j.gr.2011.07.017 
Romagna, G., Costa, R. R. (1988). Jazida de zinco e chumbo de Morro Agudo, Paracatu, Minas Gerais. In: C. Schobbenhaus, C. E. S. Coelho (Eds.). Principais Depósitos Minerais do Brasil (III, 83-90). Brasília: DNPM.

Santana, A. V. A. D. (2011). Estratigrafia, sedimentologia e proveniência das unidades superiores do Grupo Vazante na região da fazenda Fagundes, Paracatu, MG. Dissertação (Mestrado). Brasília: Instituto de Geociências - Universidade de Brasília, 136 p.
Valeriano, C. M., Dardenne, M. A., Fonseca, M. A., Simões, L. S. A., Seer, H. J. (2004). A Evolução Tectônica da Faixa Brasília. In: V. Mantesso Neto, A. Bartorelli, C.D.R. Carneiro, B.B. Brito Neves (Eds.). Geologia do Continente Sul-Americano - Evolução da obra de Fernando Flávio Marques de Almeida. São Paulo: Beca, p. 575-592.

Walker, R. G., James, N. P. (Eds.). (1992). Facies Models: Response to sea level change. Toronto: Geological Association of Canada, 409 p. 